\title{
A bibliography of picture-memory studies
}

LIONEL STANDING, BARBARA BOND, JOAN HALL, and JEAN WELLER

Bishop's University, Lennoxville, P.Q., Canada 


\section{A bibliography of picture-memory studies*}

\section{LIONEL STANDING†, BARBARA BOND, JOAN HALL, and JEAN WELLER Bishop's University, Lennoxville, P.Q., Canada}

The following bibliography includes all papers known to the authors which deal with the learning of pictorial material or visual forms, plus all known papers which are closely related to this field. Under the latter category, papers have been included on the following topics: eidetic imagery, imagery in verbal learning, pathological visual-memory deficits, facial recognition, and the learinins of object displays. The criterion for selection has been applied leniently enough to encompass all relevant material, including papers of borderline applicability to picture memory as interpreted in the narrowest sense.

The period covered by the bibliography extends from the last century to the present day. The main method employed has been a detailed search of Psychological Abstracts (1927-1972) and of the bibliography in each paper located. While the bibliography overall is as comprehensive as possible, for the years $1960-1970$ it is hoped that it is exhaustive. For this decade, a detailed extra search was made of all joumals published by the Psychonomic Society, Southern Universities Press, the Journal Press, and the APA, as well as the American, British, and Canadian Journals of Psychology. The bibliography contains 685 items.

\section{BIBLIOGRAPHY}

AIKEN, E. G. Linguistic and imaginal mnemonics in paired-associate recall. Psychonomic Science, 1971, 24, 91-93.

ALIPORT, G. W. Eidetic imagery. British Journal of Psychology, 1924, 15, 99-110.

ALI,PORT, G. W. The eidetic image and after-image. American Journal of Psychology, 1928,40,418.

ALLPORT, G. W. Change and decay in the visual memory image. British Journal of Psychology, 1930, 21, 133.148.

ALTEMEYER, R. A., FULTON, D., \& BER NEY , K. Long-term memory improvement: Confirmation of a finding by Piaget. Child Development, 1969, 40. 845-857.

AMMONS, R. B. Experiential factors in visual form perception: I. Review and formulation of problems. Journal of

*This work was supported by Grants APA-0396 (National Research Council of Canada) and 9401-50 (Defence Research Board of Canada) to the first author. Invaluable assistance was received from Yolande Dubois and Philip Smith

+Now at Department of Psychology, Universitv of $\mathrm{St}$. Andrews, Fife, Scotland.
Genetic Psychology, 1954,84, 3-25.

ANDERSON, N. S., \& LEONARD, J. A The recognition, naming, and reconstruction of visual figures as a function of contour redundancy. Journal of Experimental Psychology, 1958, 56 $262-270$

ANDERSON, R. C. Encoding processes in the storage and retrieval of sentences. Journal of Experimental Psychology, $1971,91,338-340$.

ANDERSON, R. C., \& HIDDE, J. L. Imagery and sentence learning. Journal of Educational Psychology. 1971, 62 . 526-530.

ARBUCKLE, T. Y, Mediational instruction, stage of practice, presentation rate, and retrieval cue in paired-associate learning. Journal of Experimental Psychology, $1971,88,396-402$

ARNOULT, M. D. Transfer of predifferentiation training in simple and multiple shape discrimination. Journal of Experimental Psychology, 1953, 45, 401-409.

ARNOUI,T, M. D. Recognition of shapes following paired-associates pretraining. In G. Finch and F. Cameron (Eds.) Symposium on Air Force Human Engineering, Personnel and Training Research. Washington, D.C: National Academy of Sciences-National Research Council Publications, 1956, 455, 1-9.

ARNOULT, M. D. Familiarity and recognition of nonsense shapes. Journal of Experimental Psychology, 1956, 51 , 269-276.

ASCH $S$ peformulation of the problem of association. American Psychologist, 1969. 24, $92-102$

ASCH, S E, CERASO, J, \& HEIMER, W Perceptual conditions of association. Psychological Monographs, 1960,74 , 48 p. (Whole No. 490 ).

ATKINSON, R. C., HANSEN, D. N., \& BERNBACH, H. A. Short-term memory with young children. Psychonomic Science, 1964, 1, 255-256.

ATTNEAVE, F. Symmetry, information and memory for patterns. American Journal of Psychology, 1954, 61, 18.3-193.

ATTNEAVE, F. Transfer of experience with a class-schema to identification-learning of patterns and shapes. Journal of Experimental Psychology, 1957, 54, B 1-88

ATWOOD, G. E. An experimental study of visual imagination and memory. Cognitive Psychology, 1971, 2, 290-299.

AVANT, L, L \& BEVAN,W, Acquisition of class responses when the number of cases per stimulus class was varied. Journal of General Psychology, 1968,78. 299-240.

AVANT, L. L., \& BEVAN, W. Recognition of a stimulus class member after training with varied numbers of cases per class. Jourral of General Psychology, 1968, 78, $241-246$.

BAHRICK, H. P. Discriminative and associative aspects of pictorial paired-associate learning: Acquisition and retertion. Journal of Experimental Psychology, 1969,80, 113-119.

BAHRICK, H. P. Discriminative and associative aspects of retroactive inhibition. Quarterly Journal of Experimental Psychology, 1970, 22, 565-573.

BAHRICK, H. P., \& BAHRICK, P. Inciependence of verbal and visual codes of the same stimuli. Journal of Experimental Psychology, 1971, 91, 344-346.

BAHRICK, H. P.. \& BOUCHER, B. Retention of visual and verbal codes of the same stimuli. Journal of Experimental Psy chology, 1968, 78, 417-422.

BAHRICK, H. P., CLARKE, S., \& BAHRICK. P. Generalization gradients as indicants of learning and retention of a recognition task. Journal of Experimental Psychology, 1967, 75, 464-471.

BARBER, T. $X$. The eidetic image and hallucinatory behavior: A suggestion for future research. Psychological Bulletin, $1959,56,236$

BARTHOLOMEUS, B. N., \& DOEHRING, D. G. Development of naming responses to meaningful nonverbal sounds. Perceptual \& Motor Skills, 1971, 32, 195-204.

BACMEISTER, A. A., KELLAS, G., \& GORDON, D. Backward associations in paired-associate learning of retardates and normal children. Child Development. $1970,41,355-364$.

BEGG, I., \& PAIVIO, A. Concreteness and imagery in sentence meaning. Journal of Verbal Learning \& Verbal Behavior, $1969,8,821-827$

BEIJK-DOCTER, M. A., \& ELSHOUT, J, Veldafhankelijkheid en geheugen met betrekking tot sociaal relevant en sociaal n i e t - relevant materia a $l$. (Field-dependency and memory with reference to socially and not-socially relevant material.) Nederlands $T$ ijdschrift voor de Psychologie en hat Grensgebieden, 1969.24, 267-279.

BENSON, D. F., \& GREENBERG, J. P $V$ isual form agnosia: A specific defect in $v$ isual discrimination. Archives of Neurology, 1969, 29, 82-89.

BENTON, A. L. A multiple choice type of the Visual Retention Test. American Medical Association Archives of Neurology \& Psychiatry, Chicago. 1950. $64,699-707$

BENTON, A. L., \& COLLINS, N. T. Visual retention test performance in children: normative and clinical observations. Archives of Neurology \& Psychiatry, Chicago, 1949, 62, 610-617.

BENTON, A. L., \& VAN ALLEN, M. W. Impairment of facial recognition in patients with a cerebral disease. Cortex. $1970,4,344-358$.

BERLA, E., PERSENSKY, J. J., \& SENTER, R. J. Learning time with a mnemonic system. Psychonomic Science, $1969,16,207-208$

BERLYNE, D. F.. \& BORSA, D. M Uncertainty and the orientation reaction. Perception \& Psychophysics, 1968, 3 , 77-79.

BERMAN, A. Successive reproductions of visually perceived forms. Psychological Bulletin, 1939, 36, 573-574.

BETTS C $\mathrm{H}$. The distribution and functions of mental imagery. New York: Teachers College, Columbia Contributions to Education. 1909.

BEVAN, W., \& AVANT, L. L. The role of the thematic relationship between focal and contextual stimuli in recall. Journal of Verbal Learning \& Verbal Behavior, $1969,8,185-190$.

BEVAN, W. \& STEGER, J. A. Free recal and abstractness of stimuli. Science $1971,172,597-599$.

BLAIR, F. X. A study of the visual memory of deaf and hearing children. American Annals of the Deaf, 1957, 102, 254-263.

B],OOM, S. W, Recognition memory for picturis and their word labels. 
Dissertation Abstracts International. $1971,32,3657$

BOAT, B. M.. \& CLIFTON, C.. JR. Verbal mediation in four-rcar-old children. Child Development. 1968, 39,505-514.

BOCHAROVA. S. P. Vliyanie informativnoi" tsennosti ob"ektov na uroven' neprosz bol'nogo Lapominaniya. (The effect of the informational value of objects on the level of involuntary retention.) Voprosy Psikhologii, 1968. 14. 86-95.

BOLLER, F.. \& DE RE.NZI, F. Relationship between risual memory defects and hemispheric locus of lesion. Neurology, $1967,17,1052-1058$

BOLT, M. Imagery in associative learning and memory. American Journal of Psychology, 1971.84,246-252.

BOLTWOOD, C. E.. \& BLACK, K. A. The delineation and application of three mnemonic techniques. Psvihonomic Srience, 1970. 20, 339-341.

BONTE, $T$. Die personale Bedeutsamkeit der cidetischen Anlage unter besondere Berücksichtigung ihrer Beziehung zum intellectuellen Leben. (The personalistic importance of the eldetic tendency. especially in its relation to the intellectual life.) In: Untersuchungen über die eidetische Veranlagung von Kindern und Jugendlichen: Beihefte zum Zeitschrift für angewandte Psychologie, 1928, 43, 1. 110.

BONTE. T. Dis eidetische Anlage und ihre Bedeutung fur Frziehung und ('nterricht. Leipzig: Barth, 1934

BOURISSEAU. W.. DAVIS, O. L., \& YAMANOTO. K. Sense-impression responses to differing pictorial and verbal stimuli. $\mathrm{AV}$ Communication Review. $1965,13,249-258$

BOUSFIEI,D, W. A., BERKOWITZ, H., \& WHITMARSH, G. A ssociative clustering in the recall of minimally meaningfu] geometric designs. Canadian Journal of Psychology, 1959,13,281-287.

BOUSFIELD. W. A.. ESTERSON, J., \& WHITMARSH. $G$. $A$. The effects of co.sconitant colcred and uncolored pictorial representations on the learning of stimulus words. Journal of Applied Psvchology. 1957, 41, 165-168.

BOUSFIELD, W. A.. HERMAN, P. N., \& WHITMARSH, $G$. A. The learning of verbal associative responses elicited by non-verbal stimuh. Journal of General Psvchology, 1965, 72, 221-228.

BOWER. G. H. Analysis of a mnemonic device. American Scientist, 1970, 58, 496-5 10 .

BOWER. G. H. Imagery as a relational organizer in assoclative learning. Journal of Verbal Learming \& Verbal Behavior. $1970,9,529-533$

BOWER , G. H.. \& WINZENZ, D. Comparison of associative learning strategies. Psychonomic Science, 1970. 20. $119-120$

BOWERS. H. Memory and mental imagery. British Journal of Psvchology, 1931, 21 , 271-282.

BOWERS, H. Visual imagerv and retention. British Journal of Psvchology. 1932, 23 , $180-195$

BOWERS, II. Visual in:agery and "observation." Journal of Educatronal Psvchology. 1932. 23. $441-445$.

BRADLFY. P. A.. HOEPFNER, R., \& GUILFORD. J. P. A factor analysis of figural-memorv abilities. Reports from the Psychological Laboratory. Unjversity of Southern California, 1969. 43, $32 \mathrm{p}$

BRADSHAW, I. L.. \& WALLACE, G. Nodels for the processing and identification of faces. Perception \& Psychophysics, 1971 1.9,443-448.

BRANDT, H. F, Ocular patterns in visual learning. American Journal of Psychology, 1941.54,528-535.

BRTNGELMINN. J. C. Valdierung des
Bidderkennungstestes im Grugerversuch. (Valudation of the Picture Recognition Test in group administration.) Zeitschrift fur Psvchologische Diagnostik, 1958,6 . 3-17.

BRENGELMANN, J, C. Preference for upright structure in memory-traces. Psychologische Forschung, 1967, 36 . 274-280.

BREWER, W, F. Visual memory, verbal encoding and hemispheric localization. Cortex, 1969, 5, 145-151.

BRIGGS, G. G.. HAWKINS, S., \& CROVITZ. H. F, Bisarre images in artificial memori. Psychonomic Science, $1970,19,353$.

BROOKS. L. $R$. The suppression of isualization by reading. Quarterly Journal of Experimental Psychology. 1967. 19, 289-299.

BROOKS, L. R. Spatial and verbal components of the act of recall. Canadian Journal of Psychology, 1968, 22, 349-368.

BROOKS, L. R. An extension of the conflict between visualization and reading. Quarterly Journal of Experimental Psychology, 1970, 22, $91-96$.

BROOKS, R. M.. \& GOLDSTEIN, A. G. Recognition by children of inverted photographs of faces. Child Development. $1963,34,1033-1040$

BROWN, B. B. Visual recall ability and eye movements. Psychophysiology, 1968, 4. 300-306

BROWN, W. Growth of "memory images." American Journal of Psychology, 1935. 47. 90-102.

BRUNER, J. S., BUSIEK, R.. \& MINTURN, A. Assimilation in the immediate reproduction of visually perceived figures. Journal of Experimental Psychology, $1952,44,151-135$

BRUNSIVIK, E.. GOLDSCHEIDER, L., \& PILEK. F. Untersuchungen zur Entwicklung des Gedächtnisses. (Investigations of the development of memory.) Zeitschrift für angewandte Psychologie. 1932. Beiheft 64 .

BRYANT. P. E. The effects of verbal labelling on recognition of pictures and names in severely subnormal and normal children. Journal of Mental Deficiency Research, $1965,9,237-244$.

BUGELSKI, B. H. Images as mediators in one-trial paired-associate learning: II Self-timing in successive lists. Journal of Experimental Psychology, 1968. 77, 328-334.

BUGELSKI. B. R. Words, things and images. American Psychologist. 1970, 25. 1002-1013.

BUGELSKI, B. R., KIDD, E.. \& SEGIIEN. $J$. Image as a mediator in one-trial pared-associdte learning. Journal of Experimental Psychology, 1968.76, 69.73.

BLETON, A.. \& IUELLER. R. Successive reproductions of visuallv perceived forms. Journal of Genetic Psychology, 1941, 58. 7182

BUSTAMANTE, J. A.. JORDAN, A., VILA, M.. GONZALEZ. A.. \& INSUA. A. State dependent Jearning in humans. Physiology \& Behavior, 1970, 5, 793-796.

BLTTER. M. J. Differential recall of paired associates as a function of arousal and concreteness-1magery levels. Journal of Experimental Psichology, 1970, 84. $252-256$.

BUTTER. M. J., \& PALERMO, D. S. Fffects of imagery on paired-associate recall as a function of retention interval, list length, and trials. Journal of Verbal Learning \& $V$ erbal Behavior, 1970, 9, $716-719$

B L T TERS A S S M UELS, I., Short-term visual and auditory memory disorders after parietal and frontal lobe damage. Curtex. 1970.6.440-459.
BYKOVA, G. V. Rol' rechı v zapominanii Lobrazhenii predmetor normal'nymi i umstvenno otstalvmi doshkol'nikams. (Role of speech in memorization of the protrayal of objects by normal and mentally retarded preschool children.) Spetsial'naya Shkola, 1968, 4, 105-110.

CAIN A. C. Special "isolated" abilities in severely psychotic young children. Psuchiatry, 1969, 32, 137-149.

CALFEE, R. C.. HETHERINGTON, E. M., \& WALTZER. P. Short-term memory in children as a function of display size. Psychonomic Science, 1966, 4, 153-154.

CALKINS. M. W. A study of immediate and delayed recall of the conrete and the visual. Psychological Review, 1898, 5, $451-456$

CAMPBELL, V.. \& FREEMAN, J. Some functions of experimentally-induced language in perceptual learning. Perceptual \& Notor Skills, 1955, 5, 71-79.

CANTOR, G. N. Effects of three types of pretraining on discrimination learning in preschool children. Journal of Experimental Psychology, 1955, 49. 339-342.

CAREY, $N$. Factors in the mental processes of school children. I. Visuał and auditory imagery: British Journat of Psychology, $1915,7,452-490$

CARMEAN, S. L.. \& WEIR, M. Effects of verbalizations on discrimination learning and retention. Journal of Verbol Learning \& Verbal Behavior, $1967,6,545-550$.

CARMICHAEL, L., HÖGAN, H., \& WALTER, A. An experimental study of the effect of language on the reproduction of visually perceived forms. Journal of Experimental Psychology, $1932,15,73-86$

CERMAK, G. W Short-term recognition memory for complex free-form figures. Psychonomic Science. 1971, 25, 209-211. CHATEAU, J. Le phénomèné d"expansion" dans les images conceptuelles. (The ohenomenon of "expansion" in conceptual images.) Enfance, 1969, 5. $277 \cdot 294$.

CHEBYKIN, D. A. Faktor vremeni $v$ analize posledovatel'nosti raspredeleniya razdrazhitelei $u$ detei. (The factor of time in the analysis of the sequential distribution of stimuli in children.) Zhurnaf Vysshei Nervnoi Deyatel'nosti. $1968,18,280 \cdot 286$.

CHOVAN. W. L. Role of vocal labeling in memory for object arrangements by deaf and hearing children. Perceptual \& Motor Skills, $1972,34,59-62$

CHOVAN, W. L. Conceptual organization of recall in an object arrangement task with deaf and hearing children. Perceptual \& Motor Skills, 1972, 34,742.

CHOVAN W. L \& M CGETTIGAN, J. F. The effects of rocal mediating responses on visual motor tasks with deaf and hearing children. Exceptional Children, $1971,37,435-440$

CHRISTAZ, R. E. Factor analvtic study of visual memory. Psychological Monographs, 1958, 72(13, Whole No. 466)

CHRISTIANSEN, T. Visual imagery as a factor in teaching elaborative language to mentally retarded children. Exceptional Children, 1969, 35.539-541.

CHRISTIANSEN T. $\&$ STONE, $D, R$. Visual imagery and level of mediator abstractness in induced mediation paradigms. Perceptual \& Motor Skills. $1968,26,775-779$.

CICOGNANI E. Ricera sulla percerione della propria immagine (fotografica) in un gruppo di schimoirenicl. (Studies on the perception of the photographic image in a group of schizophrenics.) Neuropsichiatria, $1966,22,635-645$.

CI.ARK, II. J. Recognition memorv for random shapes as a function of 
complexity dssociation value and delay. Journal if Expe

CLAR K. H. J. R andom shape recognition at brief exposure durations. Psychonomic Science, $1968,12,245-246$.

CLARK, H. J.. \& KNOLL. R, L. Variables underlying the recognition of random shapes. Perception \& Psychophysics. 1969,5. 221-222.

CLARKE, H. M. Recall and recognition for faces and names. Journal of Applied Psychology. 1934.18,757-763.

CLOUSE. B. Selected cues in the acquisition and retention of four meaningful $C-V-C$ trigrams. Perceptual \& Motor Skills. $1971,33,83-90$

COHEN B. D., NOBLIN, C. D., \& SILVERMAN. A. J. Functional asymmetry of the human brain. Science. 1968, 162.475.477.

COHEN, D.B.. \& NELSON. W. H. Effect of differently colored incidental stimuli on cued discrimination. Perceptual \& Motor Skills, 1966, 22, 143-146.

COHEN, G. Serial position effects in the recall of picture sequences. Quarterly Journal of Experimental Psychology, $1972,24,41-47$.

COHEN, J. S., WELCH. L., \& FISICHELLI. $V$. R. An objective test of visual retention capacity. Journal of Psychology, 1951, $32,43-47$.

COHEN, R. L. Effect of verbal labels on the recall of a tisually perceived simple figure: Recognition versus reproduction. Perceptual \& Motor Skills, 1966, 23, 859-862.

COHEN, R. L. Interaction between a visually perceived simple figure and an appropriate rerbal label in recall. Perceptual \& Motor Skills, 1967, 24, 287-292.

COHEN, R. L. \& GRANSTROM, K. The role of verbalizing in the memorizing of conventional figures. Joumal of Verbal Leaming \& Verbal Behavior, 1968. 7 , 380-383.

COHEN, R. L.. \& GRANSTROM, K. Interpolated task and mode of recall as variables in STM for visual figures. journal of Verbal Learning \& Verbal Behavior, 1968, 7,653-658

COHEN, R. L.. \& GRANSTROM, K. Reproduction and recognition in short-term visual memory Quarterly Journal of Experimental Psychology. $1970,22,450-457$

COLE, M., FRANKEL, F., \& SHARP, D Development of free recall learning in children. Developmental Psychology. 1971, 4, 109-123.

COLE, M. SHARP, D. W. GLICK, J.. \& KESSEN, $W$. Conceptual and mnemonic factors in paired-associate learning. Journal of Experimental Child Psychology, 1968,6,120-130.

COLFGATE. R. L., \& ERIKSEN, C. W. Implicit speech as an encoding mechanism in visual perception. American Journal of Psychology, 1970. 83, 208-216.

COLEGROVE, F. W. The time required for recognition. American Journal of Psychology, 1899, 10, 289-292.

COLLYER, S., JONIDES J \& BEVAN, W Images as memory ads: Is bizarreness helpful? American Journal of Psychology. $1972,85,31-38$

CONYOLY M R \& HARRIS L Effects of stimulus incongruity on children's curiosity as measured by looking time and expression change. Psichonomic Science, $1971,25,232-234$

CONRAD. $R$. The chronology of the development of covert speech in children. Developmental Psychology, 1971. 5. 398-405.

COOPER, J. R.. \& BARNES, E. J Technique for measuring reproductions of visual stimuli: II. Adult reproductions of the Bender-Gestalt. Perceptual \&
Motor Skills. 1966,23, $1135-1138$

COOPER, J. R.. DWARSHUIS, L.. \& BLECHAAN. G. Technique for measuring reproductions of visual stimuli III. Bender-Gestalt and severity of Skills, 1967, 25, 506-508

CORSINI, D. A. The effect of non-rerbal cues on the retention of kindergarten children. Child Development, 1969.40, 599-607.

CORSINI, D. A. The effect of type of redundancy on retention in preschool children. Psychonomic Science, 1970.19. 117-118.

CORSINI. D. A., JACOBL'S. K. A., \& LEONARD, S. D. Recognition memory of preschool children for pictures and words. Psychonomic Science. 1969, 16. 192-193.

CRAFTS. L. W. Whole and part methods with visual spatial material. American Journal of Psychology. 1932, 44, j26-534.

CRAFTS, L. W. Primacy and recency in the learning of visual diagrams. American Journal of Psychology, 1932, 44, 763-767.

CR A M AUSSEL, E. Images eidétiques. (Eidetic images.) Journal de Psychologie. 1926. 23, 1003-1010.

CRONBACH. L.J. Individual differences in learning to reproduce forms: A study in attention. American Journal of Psychology. 1941.54,197-222.

CROSS, J. F.. \& DALY, J. Sex. race, age and beauty as factors in recognition of faces. Perception \& Psychophysics. 1971. $10,393-396$

CROVITZ, H. F. Memory loci in artificial memory. Psychonomic Science. 1969, 16 , $82-83$.

CROVITZ. H. F. Galtor's walk: Wethods for the analysis of thinking intelligence and creatility'. New York: Harper \& Row, 1970.

CUTTS. N. A., \& MOSELEY. N. Notes on photographic memory. Journal of Psychology, 1969, 71,3-15

DAEHLER, M. W., \& WRIGHT, J.C. Visual prompting in a paired-associate mediation paradigm. Journal of Verbal Learning \& Verbal Behavior, $1968,7,148-153$.

DALLETT, K., \& WILCOX, S. G. Remembering pictures versus remembering descriptions. Psichonomic Science, 1968,11,139-140.

DALLETT, K., WILCOX. S. G., \& D'ANDREA. L. Picture memory experiments. Journal of Experimental Psychology. 1968,76, 312-320.

DANIEL T. C. \& ELLIS, H. Stimulus codability and long-term recognition memory for visual form. Journal of Experimental Psychology, 1972, 93. 83-89.

DANKS, J, H. Encoding of novel figures for communication and memory. Cognitive Psychology, 1970,1, 179-191.

DAVES, W. F., \& RINN. R. C. Free recall of object categories as a function of number of presentations of varied or repeated specimens. Psychonomic Science. 1971, 22. 203-205

DAVES, W. F \& RINN. R. C. The variety effect in free recall as a function of prerecall activity. Psychonomic Science, 1971.22, 226-227.

DAVIDON R S. \& LONGO N. Conceptual development reflected in age differences in associations to names and pictures of objects. Journal of Genetic Psychology, 1960,96, 85-92

DAVIDSON, R. E Mediation and ability in paired-associate learning. Inurnal of Educational Psychology, 1964. 55. 352-356.

DAVIDSON, R. E., \& ADAMS. J. F. Verbal and imagery processes in children's paired-associate learning. Journal of Experimental Child Psychology. 1970. 9. 429-435.
DAVIFS. G. M. Rerognition memory for pictured and named objects. Jourmal of Experimental Child Psycholngx. 1969. 7 $4.48-458$

DAVIES, G. M. Quantitative and qualitative aspects of memory for picture stimuli. Journal of Experimental Child Psychology, 1972,13,382-393.

DAVIES, G. M. The influence of verbal labelling on the retention of pictured stimuli: An alternative viewpoint. Journal of Special Education. in press.

DAVIS. F. C. The functional significance of imasery differences. Journal of Experimental Psychology. 1932. 15. 630-661.

DEICH. R. F. Reproduction and recognition as indices of perceptual impairment. American Journal of Mental Deficiencr. $1968.73,9-12$

DEL N, P. S. Success in recail as a furction of success in implementation of mnemonic instructions. Psychonomic Science, 1968,12,153-154.

DELIN, P. S. An experiment examining list-learning with and without the mnemonic use of bizarre associations. Journal of General Psychology. 1969.81. 249-260.

DELIN, $P, S$. The learning to criterion of a serial list with and without mnemonic instructions. Psychonomic Science. 1969. 16, 169-170

DELIN, $P$. S. Learning and retention of English words with successive approximations to a complex mnemonic instruction. Psychonomic Science. 1969. $17,87-89$.

DELIN, P. S. The effects of mnemonic instruction and list length on seria learning and retention. Psychonomic Science, 1969,17,111-113

DENISON, J. W. Relationship of auditory and $v$ isual perceptual strengths to methods of teaching a paired-associate task to first graders. Perceptual \& Motor Skills, 1971, 32. 218

DENNER. B., \& CASHDAN, S. Sensory processing and the recognition of form in nurserv-school children. British Journal of Psychology, 1967, 58, 101-104.

DENO, S. L. Multiple discrimination learning as a function ot conceptual similarity among picture and word stimuli. Unpublished doctoral dissertation, Cniversity of Minnesota. 1965 .

DENO, S. L. Effects of words and pictures as stimuli in learning language equivalents. Journal of Educational Psychology, 1968.59,202-206.

DENO, S. L., JOHNSON, P. E.. \& JENKINS, J. R. Associative similarity of words and pictures. AV Communication Review. 1968, 16, 280-286.

DEREGOWSKI, J. B. Pictorial recognition in subjects from a relatively pictureless environment. African Social Research. $1968,5,356-364$.

DE RENZI, E., \& SPINNI.ER, H. Facial recognition in brain-damaged patients. Neurology, 1966, 16,145-152.

DE RENZI. E.. \& SPINNLER, $H$. The influence of verbal and non-verbal defects on visual memory tasks. Cortex, 1966, 2. 322-335.

DE RENZI, E., \& SPINNLER, H. Visual recognition in patients with unilateral cerebral disease. Journal of Nerrous \& Mental Disease. 1966, 142,515-525.

DERENZI, E. FAGLIONI. P.. \& SPINNLER, Hi, The performance of patients with unilateral brain damage on face recognition tests. Cortex. 1968. 4 $17 \cdot 35$.

DE RENZI, E., SCOTTI, G., \& SPINNLER. $H$. Perceptual and associative disorders of visual recognition. Neurology, 1969. 19 634-641.

DE RIVERA, J. Some conditions governing the use of the cue-producing response as an explanatory device. Journal of 
Experimental Psichology, 1959, 57 299-304.

DEVOR, G. M., \& STERN, C. Objects versus pictures in the instruction o young children. Journal of School Psychology, 1970, 8, 77-81.

DIDLO J H Operant conditioning procedures applied to eidetic imagery: A preliminary investigation. Dissertation Abstracts International, 1970, 30 $4137-4138$

DIETZE, D. The facilitating effect of words on discrimination and generalization. Journal of Experimental Psychology, $1955,50,255 \cdot 260$.

DILLEY, M. G., \& PAIVIO, A. Pictures and words as stimulus and response items in paired-associate learning of young children. Journal of Experimental Child Psychology, 1968, 6, 231-241.

DIMITR OV $M$. (The movement of colors in the field of spontaneous eidetic images.) Annuaire Universitet Sofia, 1933, 30, 1

DOMINOWSKI. R. L., \& GADLIN, $H$ Imagery and paired-associate learning. Canadian Journal of Psychology, 1968. $22,336-348$

DONALDSON, M., \& STRANG, H. Primacy effect in short-term memory in young children. Psychonomic Science, 1969, 16 59-60.

DONDERI, D., CASE, B., ROSSOFF, L., \& WILLIS, J. Change in visual memory following discrimination learning. Canadian Journal of Psychology, 1970. $24,401-416$

DOOB, L. W. Exploring eidetic imagery among the Kamba of Central Kenya. Journal of Social Psychology, 1965, 67. 3-22.

DOOB. L. W. Eidetic imagery: A cross-cultural will-o'-the-wisp? Journal of Psychology, 1966,63, 13-34.

DROBA D. D Effect of printed information on memory for pictures. Museum News, 1929, 1,6-8.

DROBA, D. D. Effect of order of presentation on the recall of pictures. Journal of Educational Psychology, 1931. ¿2, ì77-682.

DRUMRIGHT, R. G. Some factors influencing remembering of pictorial and prose materials. Dissertation Abstracts. $1957,17,170$.

DLCHARME, R., \& FRAISSE, P. Etude génétique de la mémorisation do mots et d'images. Canadian Journal of Psychology, 1965, 19, 253-261.

DUCKER, H.. \& TAUSCH, R. Über die Wirkung der Veranschaulichung von Unterrichtsst offen auf das Behalten. (The effect of visual aids on the retention of school-subjects.) Zeitschrift für experimentelle und angewand te Psychologie, 1957, 4, 384-400.

DUKES, W. F., \& BEVAN, W. Stimulus variation and repetition in the acquisition of naming responses. Journal of Experimental Psychology, 1967,.74 $178 \cdot 181$.

DWIVEDI, C. B Role of verbal labeling in perceptual learning: Some confirmatory evidences to differentiation hypothesis. Indian Psychological Review, 1967, 3 123-127.

DWYER, F. M. Adapting visual illustrations for effective learning. Harvard Educational Review, 1967, 37, 250-263.

DWYER, F. M. The effect of stimulus variability on immediate and delayed retention. Journal of Experimental Education, 1969, 38, 30-37

DWYER, F. M. The effect of image size on visual learning. Journal of Experimental Education, 1970, 39, 36-41.

EGETH, H., \& SMITH, E. E. Perceptual selectivity in a visual recognition task. Journal of Experimental Psychology, $1967,74,543-549$

ELLIS, H. C. Associative variables in visual form recognition. Psychonomic Bulletin, $1967,1,3$.
ELLIS, H. C. Transfer of stimulus predifferentiation to shape recognition and identification learning: Role of properties of verbal labels. Journal of Experimental Psychology, 1968. 78 401-409.

ELLIS, H C \& DANIEL, $T$, C Verbal pocesses in long-terin stimulus-recognition memory. Joumal of Experimental Psychology, 1971, 90 18-26.

ELLIS, H. C., \& MULLER, D. Transfer in perceptual learning following stimulus predifferentiation. Journal of Experimental Psychology, 1964, 68 388-395.

ELLIS, H. C., MULLER, D. C.. \& TOSTI, D. T. Stimulus meaning and complexity as factors in the transfer of stimulus predifferentiation. Journal of Experimental Psychology, 1966, 71 629-633.

ELLIS, N. R., \& MUNGER, M. Short-term memory in normal children and mental retardates. Psychonomic Science, 1966. 6. 381-382.

ELLIS, N., \& PORTER, W. The function of stimulus meaning and ability level in discrimination learning. Psychonomic Science, 1966, 6, 463-464.

ELLIS, N. McCARVER, R \& ASHURST H. Short-term memory in the retarded: Ability level and stimulus meaningfulness. American Journal of Mental Deficiency, $1970,75,72-80$

ELLIS, N., DETTERMAN, D., RUNCIE, D. McCARVER, R., \& CRAIG, E. Amnesic effects in short-term memory. Journal of Experimental Psychology, 1971, 89, 357-361.

EPSTEIN, W. Varieties of perceptual learning. New York: McGraw-Hill, 1967. EPSTEIN, W., ROCK, I., ZUCKERMAN $C$. Meaning and familiarity in associative learning. Psychological Monographs. 1960, 74, 1-22 (Whole No. 491).

ERDELYI, M. Recovery of unavailable perceptual input. Cognitive Psychology. 1970, 1,99-113.

ERNEST, C.. \& PAIVIO, A. Imagery ability in paired-associate and incidental learning. Psychonomic Science, 1969,15, $181-182$.

ERNEST, C., \& PAIVIO, A. Imagery and sex differences in incidental recall. British Journal of Psychology, 1971, 62, 67-72

ESPESETH $V$ An investigation of visual-sequential memory in deaf children. American Annals of the Deaf, $1969,114,786-789$.

FAGAN. J. Infants' recognition memory for a series of visual stimuli. Journal of Experimental Child Psychology, 1971. $11,244-250$

FAGLIONI, P., \& SPINNLER, II. Immediate and delayed recognition of nonsense figures in patients with unilateral hemisphere damage. Journal of Learning Disabilities, $1969,2,652-658$.

FANTZ, $R$. Visual experience in infants: Decreased attention to familiar patterns relative to novel ones. Science, 1964 , 146, 668-670

FARRER, D. N. Picture memory in the chimpanzee. Perceptual \& Motor Skills, $1967,25,305-315$.

FEDIO, P., \& MIRSKY, A. F. Selective intellectual deficits in children with temporal lobe or centrencephalic epilepsy. Neuropsychologia, 1969.7 . 287-300.

FEHRER, E. V. An investigation of the learning of visually perceived forms. American Journal of Psychology, 1935, 47, 187-221.

FEINAGLE, $G$, von. The new art of memory. (3rd ed.) London: Sherwood, Neely \& Jones. 1813

FELDMAN, M. Eidetic imagery in Ghana: A cross-cultural will-o'-the-wisp? Journal of Psychology, 1968, 69, 259-269.

FERGUSON, M. N. A comparison of the chain associations of nursery school and kindergarten children to action-picture timuli. Speech Monographs, 1957, 24 56-64.

FERNALD, M. R. The diagnosis of mental magery. Psychological Monographs, 1912,14, No. 58

FEUGE, R. L.. \& ELLIS, H. Generalization gradients in recognition memory of visua form: The role of stimulus meaning. Joumal of Experimental Psychology, $1969,79,288-294$

FISCHLER, I.. \& PUFF, C. R. Organization in free recall with verbal and pictorial modes of input and output. Psychonomic Science, 1971, 22, 85-87.

FITTS, P. M., WEINSTEIN, M. RAPPAPORT, $\dot{M}$., ANDERSON, N., \& LEONARD, J. Stimulus correlates of visual pattern recognition: A probability approach. Journal of Experimental Psychology, 1956, 51, 1-11.

FLAVELL, J. H., BEACH, D., \& CHINSKY $J$. Spontaneous verbal rehearsal in a memory task as a function of age. Child Development, 1966, 37, 283-299.

FLAVELL, J. H., FRIEDRICHS, A. G., \& HOYT, J. D. Developmental changes in memorization processes. Cognitive Psychology, 1970, 1, 324-340.

FOZARD, J. L. Apparent recency of unrelated pictures and nouns presented in the same sequence. Journal of Experimental Psychology, 1970, 86 . $137 \cdot 143$.

FOZARD, d. L., \& LAPINE, R. Comparison of discrimination of recency of pictures and names of common objects. American Psy chologist, 1968, 23, 658.

FRAISSE, $P$. La verbalisation d'un dessin facilite-t-elle son évocation par l'enfant? (Does verbalization of the design facilitate its recall by the child?) Année Psy chologique, 1970, 70, 109-122.

FRANKS, J. J., \& BRANSFORD, J. D. Abstraction of visual patterns. Journal of Experimental Psychology, 1971, 90. 65-74

FRANZEN, $R$ An examination of the effect of number of advertisements in a magazine upon the 'visibility' of these advertisements. Journal of Experimental Psychology, 1940, 24, 791-801.

FRENCH, R. S. Number of common elements and consistencv of reinforcement in a discrimination learning task. Journal of Experimental Psychology, 1953, 45, 25-34.

FRENCH, R. S, Identification of dot patterns from memory as a function of complexity. Journal of Experimental Psychology, 1954, 47, 22-26.

FRENCH, R. S. Pattern recognition in the presence of risual noise. Journal of Experimental Psychology, 1954, 47. 27-31.

FREY, W. G., \& FOZARD, J.L. Effect of presentation time on the judged recency of pictures. Journal of Experimental Psychology, 1970, 85, 105-110.

FRIEDMAN，M. P.. REED， S. K. \& CARTERETTE, E, C. Feature saliency and recognition memory for schematic faces. Perception \& Psychophysics, 1971 , $10,47-50$

FRIJDA, $N$. H., \& VAN DE GEER, J. P. Codability and recognition: An experiment with facial expressions. Acta Psychologica, 1961, 18, 360-367.

FROST, N. Clustering by visual shape in the free recall of pictorial stimuli. Journal of Experimental Psychology, 1971, 88, 409-413.

FURST. B. Stop forgetting: How to develop your memory and put it to practical use. New York: Greenburg, 1949.

FURST, B. The practical way to a better memory. New York: Fawcett World Library, 1957

FURST, B. You can remember. Chicago: Mamory \& Concentration Studies, 1963. FURTH, H. G. Visual paired-associates task 
with deaf and hearing children. Journal of Speech \& Hearing Research, 1961. 4 $172+177$.

GAGNE. R. M. The effect of sequence of presentation of similar items on the learning of paired associates. Journal of Experimental Psychology, 1950,40 , $61-73$.

GAGNE, R., \& GIBSON, J. J. Research on the recognition of aircraft. In J. J. Gibson (Ed.). Iotion picture training and research. Report No. 7, Army Air Force Aviation Psychology Program, U.S. Government Printing Office. Washington, D.C., 1947

GAINOTTI. G., \& TIACCI. C. Patterns of drawing disability in right and left hemispheric patients. Neuropsychologia, 1970,8. 379-384.

GALIUP. G. Chimpanze es: Self-recognition. Science. 1970,167 86.87

GALLUP, G. It's done with mirrors-chimps and self-concept. Psychology Todar. March 1971, 58-61.

GALPE $R$ E Recognition of faces: The effect of previous exposure to different expressions. Doctoral dissertation, New York University, 1969.

GALPER, R, E. Recognition of faces in photographic negatives. Psrchonomic Science. 1970, 19,207-208.

GALPER, R. E., \& HOCHBERG, J. Recognition memory for photographs of faces. American Journal of Psychology, $1971,84,351-354$

GARNER. W. R. To perceive is to know, American Psychologist, 1966, 21, 11-19.

GAZZANIGA, M. S. The split brain in man. Scientific American, $1967,217,24-29$

GAZZANIGA, M. S. Short-term memory and brain-bisected man. Psychonomic Science, $1968,12,161-162$

GAZZANIGA M S. \& HILLYARD, S. A. Language and speech capacity of the right hemisphere. Neuropsychologia, 1971, 9 , $273-280$.

GAZZANIGA. M. S.. \& SPERRY, R. W. Language after section of the cerebral commissures. Brain, 1967.90. 131-148,

GEFFEN, G., BRADSHAW, J. L.. \& WALLACE, G. Interhemispheric effects on reaction time to verbal and nonverbal visual stimuli. Joumal of Experimental Psrchology, 1971, 87, 415-422.

GENGERELLI. J. A. Some quantitative experiments with eidetic imagery. American Journal of Psychology, 1930, $42,399 \cdot 404$

GERST, M. S. Symbolic coding processes in observational learning. Journal of Personatity \& Social Psychology, 1971, 19, 7-17.

GIBSON. E. J. Principles of perceptual learning and development. New York: Applet on-Century-Crofts, 1969.

GIBSON, J. J. The reproduction of visually perceived forms. Journal of Experimental Psychology, 1929,12,1-39.

GIBSON, J. J, \& GIBSON, E. J. Perceptual learning: Differentiation or enrichment? Psychological Review, 1955, 62, 32-41.

GLANZER, N.\& CLARK, W.H. Accuracy of perceptual recall: An analysis of organization. Journal of Verbal Learning \& Verbal Behavior, 1962, 1, 289-299.

GLANZER, M.. \& CLARK, W. H. The verbal loop hypothesis: Conventional figures. American Journal of Psychology, $1964.77,621-626$.

GLESER, IF, D. Zur Untersuchung der Mechanismen der Bilderkennung im Wahrnehmungssystem. (The examination of recognition of pictures in perception, 80-91.

GLIDDEN, L. M. Meaningfulness, serial position and retention interval in recognition short-term memory. Journal of Experimental Child Psychology, 1972, $13,154-164$

GOLDMEIER, E. Progressive changes in memory traces. American Journal of
Psychology. 1941, 54, 490-503

GOLDSTEIN, A. G. Learning of inverted and normally oriented faces in children and adults. Psychonomic Science, 1965 , 3, 447-448

GOLDSTEIN, A. G., \& CHANCE, J. E. Recognition of children's faces. Child Development, 1964, 35, 129-136.

GOLDSTEIN, A. G., \& CHANCE, J. E, Recognition of children's faces: II. Perceptual \& Motor Skills, 1965, 20, 547-548.

GOLDSTEIN, A. G. \& CHANCE, J. E. Visual recognition memory for complex configurations. Perception \& Psychophysics, 1971,9,237-241.

GOLDSTEIN, J.. LOCKE, J., \& FEHR, F, Children's prerecall phonetic processing of pictures and printed words. Psychonomic Science. 1972, 26, 314-316.

GOLLIN, E. S. Derelopmental studies of visual recognition of incomplete objects. Perceptual \& Motor Skills, 1960, 11. 289-298

GOLLIN, E. Further studies of risual recognition of incomplete objects. Perceptual \& Motor Skills, 1961, 13, $307-314$

GOLLIN, E, S. Factors affecting the visual recognition of incomplete objects: A comparative investigation of children and adults. Perceptual \& Motor Skilis, 1962 , $15,583-590$

GOLLIN, E. S. Perceptual learning of incomplete pictures. Perceptual \& Motor Skills, $1965,21,439-445$.

GOLLIN, E. S. Word labels and perceptual recognition. Psychonomic Science, 1967, $7,63-64$

OULD, R. L. A test of memory for names and faces. Journal of Applied Psychology $1917,1,321-324$

GOULET, L. R., \& STERNS, H. L Verbal-discrimination learning and transfer with verbal and pictorial materials. Journal of Experimental Child Psychology, 1970, 10, 257-263.

GREKOV B. A. Nekotorye zakonomernost izmeneniza pamrati $"$ starcheskom vozraste. (Some lawful memory changes in senescence.) Voprosy Psikhologii. $1968,14,67-79$

GRESSOT, M. Essai sur l'image eidétique et le probleme de la vision. Schweizer Archiv für Neurologie und Psychiatrie, $1950,66,87-122$.

GRONINGER, L. D. Mnemonic imagery and forgetting. Psychonomic Science. $1971,23,161-163$

GROPPER, G. L. Why is a picture worth a thousand words? AV Communication Review, 1963, 11,75-95.

GROPPER, G. L. Controlling student responses through programmed visua presentations. Perceptual \& Motor Skills, $1964,18,703-704$.

GROPPER, G, L. Does 'programmed' television need active responding? AV Communication Review, $1967,15,5-22$

GUMMERMAN, K., \& GRAYS, C. Recall of visually presented material: An unwonted case and a bibliography for eidetic imagery. Psychonomic Monograph Supplements, 1971, 4(10, Whule No.58)

GUPTON, T., \& FRINCKE, G. Imagery mediational instructions, and noun position in free recall of noun-verb pairs. Journal of Experimental Psychology. $1970,86,461-462$.

GURNEE, $H$. Comparative retention of open and closed visual patterns. Psychological Bulletin, 1940, 37, 568

GURNEE, H., WITZEMAN, B. E. \& HELLER, M. Comparative retention of open and closed visual forms. Jouma of Experimental Psychology, 1940,27 66-70.

HABER, R. N. Eidetic images. Scientific American, $1969,220,36-44$

HABER, R. N. How we remember what we see. Scientific American, 1970, 222 104-112.

HABER, R. N.. \& ERDELYI, M. H
Emergence and recovery of initially unavailable perceptual material. Journal of Verbal Learning \& Verbal Behavior. $1967,6,618 \cdot 628$

HABER, R. N.. \& HABER, R. B. Eidetic imagery: I. Frequeney. Perceptual \& Motor Skills, $1964,19,131-138$.

HAGEN, J.W. \& KINGSLEY, P, R. Labeling effects in short-term memory. Child Development. 1968, 39, 113-121. I A EN, J, W., MEACHAM, J.. \& MESIBOV. G. Verbal labeling, rehearsal and STM. Cognitive Psychology, 1970, 1 , $47-58$

HAITH, M. M.. MORRISON. F. J. SHEINGOLD, K., \& MNDES, P Short-term memory for risual information in children and adults. Journal of Experimental Child Psychology. 1970,9.454-469.

HAKE, H. W, \& ERIKSEN, C. W. Effect of number of permissible response categories on learning of a constant number of visual stimuli. Journal of Experimental Psychology, 1955, 50.161-167.

HAKE, H. W., \& ERIKSEN. C. W. Role of response variables in recognition and identification of complex risual forms. Journal of Experimental Psychology, $1956,52,235-243$

HALL, V. The effects of time interval on recall. British Journal of Psychology. $1936,27,41-50$

HAMILTON, F. S. Mastering your memory New York: Grammercy, 1958

HANAWALT, N. G. Memory trace for figures in recall and recognition. Archives of Psychology, 1937, 31,89

HANAWALT, N. G, The effect of rerbal suggestion in the recall period upon reproduction of risually perceived forms. Psychological Bulletin, 1938, 35, 692

HANAWALT, N. G, \& DEMAREST, I. H The effect of verbal suggestion upon the reproduction of visually perceived forms. Journal of Experimental Psvchology. $1939,25,159-174$

HANFMANN, E. Die Entstehung visueller Assoziationen. (The development of Assul association. Zeitschrift fiur Psychologie, 1927, 105, 147-194.

HANSEN, D. N. Short-term memory and presentation rates with young chidren. Psychonomic Science, 1965, 3. 253-254.

HANSEN, W. Uber den gegewärtigen $S$ tand der eidetischen Forschung. (The present position of eidetic investigation.) Vierteljahrsschrift für wissenschaftliche pidogogik, 1929, 5, 347-383.

HARDEN, R. McG. An experment involving substitution of tape-slide programmes for lectures. The Lancet. $1969,1,933-935$

HARRIS, G. J., \& FLEER, R. Recognition memory for faces by retardates and normals. Perceptual \& Motor Skills. 1972 $34,755-758$

HEBB, D. O. Concerning imagery. Psychological Review, 1968, 75, $466-477$.

HEBB, D. O \& FOORD E N Errors of vistual recognition and the nature of the trace. Journal of Experimenta Psychology, 1945, 35, 335-348.

HECAEN, $H$ ANGELERGUES, R. Agnosia for faces (prosopagnosia). Archives of Neurology, 1962,7,92-100

HECTOR, J. Les structures mentales (Mental structures.) Rerue de Philosophie, 1928, 28, 255-321.

HEVNING, $H$. F. An investigation of retention using the methods of recall and ecognition. Australasian Journal of Psychology, 1930, 8, 305-310

HERMAN, T., BROUSSARD. I. G. \& TODD, $H . R$. Intertrial interval and the rate of learning serial order picture stimuli. Journal of General Psychology. $1.951,45,245 \cdot 254$.

HILL, S. D., \& HECKER, E. E. Auditory and visual learning of a paired-associate task by second grade children. Perceptual \& Motor Skills, 1966, 23,814.

HOCHBERG, J., \& BROOKS, V. Pictorial 
recognition as an unlearned ability: A study of one child's performance. American Journal of Psychology, 1962 $75,624-628$

HOCHBERG, J., \& GALPER, R. E Recognition of faces: I. An exploratory study. Psychonomic Science, 1967,9, 619-620.

HOLLENBERG, C. K. Functions of visual imagery in the learning and concept formation of children. Child Development, $1970,41,1003-1015$.

HOLLINGWORTH, H. L. Psychology, its facts and principles. New York: Appleton, 1928

HOROWITZ, A. B. Effect of stimulus presentation modes on children's recall and clustering. Psychonomic Science. $1969,14,297-298$

HOROWITZ, L. M., LAMPEL, A., \&

TAKANISHI, R. The child's memory for unitized scenes. Journal of Experimental Child Psychology, 1969, 8, 375-388

HOVING, K. L., MORIN, R. E., \& KONICK, D. S. Recognition reaction time and size of the memory set: A developmental study. Psychonomic Science, $1970,21,247-248$

HOWE, M. J. Recognition memory for photographs in homogeneous sequences. Perceptual \& Notor Skills, 1967, 24, $1181-1182$

HOWELLS, T. H. A study of ability to recognize faces. Psychological Bulletin, $1935,32,726$

HULICKA, I. M., \& GROSSMAN, J Age-group comparisons for the use of mediators in paired-associate learning. Journal of Gerontology, 1967, 22, 46-51.

H U N T ER, I. M . L. Hemor? Harmondsworth: Penguin, 1964.

HUNTER, I., \& DUTHIE, J, H. The effect of interpolated experience on visual recognition. Quarterly Journal of Experimental Psychology, 1957, 9. $21 \cdot 27$

HUSEN, T. Studier rorande de eidetiska fenomenen. (Studies dealing with eidetic phenomena.) Stock holm: Hakan Ohlssons Bok try ckeri, 1946

HYMAN, L. M. The effects of irrelevant dimensions and stimuli on two-choice discrimination learning by children. Psychonomic Science, 1971, 22, 249-250.

HYMAN, L., \& KAUFMAN, H. Information and the memory span. Perception \& Psychophysics, 1966, 1, 235-237.

ISAACS. D, L. The effect on learning of the color coding of pictorial stimuli. Doctoral dissertation, Indiana University. 1969.

ISCOE, I., \& SEMLER, I. J. Paired-associate learning in normal and mentally retarded children as a function of four experimental conditions. Journal of Comparative \& Physiological Psychology, $1964,57,387-392$.

ISHII, N. \& KURIMOTO, M. Yoji ni okeru shichikaku zukei no haji ni tsuite. $(\mathrm{On}$ the memory of visually perceived forms in children.) Japanese Journal of Educational Psychology. 1958, 5. 151-161.

JACOBUS, K., LEONARD, S. \& STRATTON, $\ddot{R}$. The effects of imagery on the paired-associate learning of adjectives. Psychonomic Science, 1971 , $25,352-354$

JAENSCH. E. R. Eidetic imagery. New York: Harcourt, Brace, 1930.

JENKIN, A. M. Imagery and learning. British Journal of Psychology, 1935, 26 , 149-164.

JENKINS, J. R. Effects of incidental cues and encoding strategies on paired-associate learning. Journal of Educational Psychology, 1968, 59. 410-413.

JENKINS, J. R., NEALE, D. C.. \& DENO, S. L. Differential memory for word and picture stimuli. Journal of Educational Psychology, 1967, 58, 303-307

JENKINS, J. R., STACK. W.. \& DENO. S.
Children's recognition and recall of picture and word stimuli. AV Communication Review, 1969. 17, $265-271$

JENSEN, A. Temporal and spatial effects of serial position. American Journal of Psychology, 1962,75, 390-400.

JOHANNES, T. Der Einfluss der Gestaltbindung auf das Behalten. 2. Der Formenwandel von Einselfiguren beim Einprägungsvorgang. (The influence of Gestait cohesion upon recall. 2. Form changes of single figures in impression.) Archiv für die gesamte Psychologie, 1939 , 104, 74-130.

JOHAN NESSON, B. Eidetische Untersuchungen in island. (Eidetic studies in Iceland.) Zeitschrift für Psychologie, 1939, 146, 161-181.

JOHNSON, D. M., \& RHOADES, C Measurement of a subjective aspect of learning. Journal of Experimental Psychology, 1941, 28, 90-92.

JOHNSON, R. B. Images as mediators in fxee recall. Journal of Experimental Psychology, 1970, 84, 523-526.

JOHNSON, R. B. More on "bizarre images in artificial memory." Psychonomic Science, 1972, 26, 101-102

JONES, A. C. Influence of mode of stimulus presentation on performance in facial recognition tasks. Cortex, 1969, 5 , 290-301.

JONES, E. C. Schema learning with low redundancy patterns. Psychonomic Science, $1970,21,74-75$.

JONES, H. E., CONRAD, H., \& HORN, A. Psychological studies of motion pictures. II. Observation and recall as a function of age. University of California Publications in Psychology, 1928, 3, 225-243.

JONES, L. W. Memory for faces and memory for names. Character \& Personality, 1935, 4, 115.119.

KAESS, W. A., \& WITRYOL, S. Memory for names and faces: A characteristic of social intelligence? Journal of Applied Psy chology, 1955, 39, 457-462.

KAPLAN, S., KAPLAN, R., \& SAMPSON, J. R. Encoding and arousal factors in frec recall of verbal and visual material. Psychonomic Science, 1968, 12, 73-74.

KARWOSKI, T. F., GRAMLICH, F, W. \& ARNOTT, P. Psychological studies in semantics: I. Free association reactions to words, drawings, and objects. Journal of Social Psychology, 1944, 20, 233-247.

KATZ, P. A. Effects of labels on children's perception and discrimination learning. Journal of Experimental Psychology. $1963,66,423-428$

KATZ, P. A \& ZIGLER, E. Effects of labels on perceptual transfer. Journal of Experimental Psychology, 1969, 80, $73-77$

KATZ, P. A., ALBERT, J., \& ATKINS, M. Mediation and perceptual transfer in children. Developmental Psychology. $1971,4,268-276$.

KATZ, P. A., KARP. B., \& YALISOVE, D. Verbal mediation of children's perception: The role of response variables. Journal of Experimental Psychology, 1970,85, 349-355.

KAUSLER, D. H., \& GOTWAY, M, R-S learning in children. Journal of Experimental Child Psychology. 1969, 8, 190-194.

KAY,H.. \& SKEMP, R. Different thresholds for recognition: Further experiments on interpolated recall and recognition. Quarterly Journal of Experimental Psychology. 1956, 8, 153-162.

KEELY, $K$. Age and task effects in short-term memory of children. Perception \& Psychophysics, 1971, 9, 480-482

KEENEY, T. J., CANNIZZO, J., \& FLAVELL, J. Spontaneous and induced rerbal rehearsal in a recall task. Child Development. 1967, 38,953-966.

KELLOGG, G., \& HOWE, M. Using words and pictures in foreign language learning. Alberta Journal of Educational Research, $1971,17,89-94$

KEMPEN, G. A. Ein informatie-theoretische reinterpretatie van het probleem der autonome geheugenveranderingen. (An information-theoretical reinterpretation of the autonomous changes in risual memory.) Gawein, 1966, 15, 0-26.

KEPPEI, G., \& ZAVORTINK, B, Further test of the use of images as mediators. Journal of Experimental Psychology, 1969,82, 190-192.

KIESOW, F. I fenomeni eidetisi e la pretesa metamorfosi psichica. (Eidetic phenomena of pretended psychic metamorphosis.) Actes de cinqième Congresse internationale de Philosophie, Naples, 1924

KIESOW, F. Kritische Bemerkungen zur Eidetik, nebst an Eidetikern und $\mathrm{Nich}$ teidetikern angestellten Beobachtungen. (Critical remarks on eidetic imagery, together with observations made upon eidetic and non-eidetic subjects.; Archiv für die gesamte Psychologie, 1927, 59, 339-460.

KIMURA, D. Right temporal lobe damage. Archives of Neurology, $1963,8,264-271$.

KINGSLEY, P. R., \& HAGEN, J. W. Induced versus spontaneous rehearsal in short-term memory in nursery school children. Developmental Psychology, $1969,1,40-46$

KIRCHNER, E. P. The vividness of connotative adjectives and their paired-associate learning. Psychonomic Science, $1970,19,83-85$.

KIRKPATRICK, E. A. An experimental study of memory. Psychological Review, $1894,1,602-609$.

KLAPP, S. T. Individual differences in nonverbal memory for visually presented material. Doctoral dissertation, University of California, Berkeley, 1969

KLATZKY, R, L. Interhemispheric transfer of test stimulus representations in memory scanning. Psychonomic Science, $1970,21,201-203$

K.ATZKV, R. I., \& ATKINSON, R. C Memory scans based on alternative test timus representations. Perception \& Psychophysics, 1970,8,113-117.

KLATZKY, R. L., \& ATKINSON, R, C Specialization of the cerebral hemispheres in scanning for information in short-term memory. Perception \& Psychophysics, $1971,10,335-338$

KLATZKY, R. L., JUOLA, J. F., \& A TKINSON, R. C. Test stimulus representation and experimental context effects in memory scanning. Journal of Experimental Psychology, 1971, 87. $281-288$

KLEIN, R. E., HALE, G. A., MILLER, L. K. \& STEVENSON, H. W. Children's paired associate learning of verbal and pictorial material. Psychonomic Science, $1967,9,203-204$.

KLUVER, H. An experimental study of the idetic type. Genetic Psychology Monographs, 1926, 1.71-230.

KLUVER, H. Studies on the eidetic type and on eidetic imagery. Psychological Bulletin, 192, 25, 69-104.

KLUVER, H. Eidetic images. Encyclopedio Bitannica (14th ed.), 1929, 8, 112.

KLUVER, H. Eidetic phenomena. Psychological Bulletin, 1932, 29. $181-203$.

KLUVER, H. The eidetic type. Proceedings of the Association for Research in Nervous \& Mental Disease, 1934, 14. $150-168$

KOEN, F. Codability of complex stimuli: Three modes of representation. Journal of Personality \& Social Psychology, 1966. $3,435-441$

KOPSTEIN, F., \& ROSHAL, S. Learning a foreign vocabulary from pictures versu words. American Psychologist, 1954.9. $407-408$. 
KOSSUTH. G.. CARROLL. $W$. ROGERS. C. Free recall of words und
objects. Developmental Psychology. $1971,4,480$

HOTHURKAR, V. Effect of interpolated recall on recognition of schematic faces. Journal of Psychological Research, 1965. 9.11-14.

KRATINA. F. Die eidetische Anlage bei Jugendichen: Eine psychologische Studie. (The eidetic characteristics of adolescents: A psychological study.) Prague: Orbis.Verlag, 1930.

KROBER. W. Über das Aufzeichnen von Formen aus dem Gedächtnis. (Concerning the drawing of forms from memory.) Zeitschrift fur angewandte Psychologie. $1938,54,273-327$.

KRUEGER, L. E. Effect of direction of sequential presentation and redundancy on short-term recognition memory. Perception \& Psychophysics, 1971.9. 121-124.

KUHLMANN, F. On the analysis of the memory consciousness for pictures of familiar objects. American Journal of Psychology, 1907, 18, 389-420.

KURTZ, K. H. Discrimination of complex stimuli: The relationship of training and test stimuli in transfer of discrimination. Journal of Experimental Psychology, $1955,50,283-292$

KURTY. K.. \& HOVLAND, C. I. The effect of verbalization during observation of stimulus objects upon accuracy of recognition and recall. Journal of Experimental Psychology, 1953. 45. 157-164.

LACHER, M., \& HAGEN, J. The relation of verbal and nonverbal encoding to serial recall performance in middle and lower class children. Proceedings of the Annual Convention of the American Psychological Association, 1971, 6 . 191-192.

LAUGHERY K , ALEXANDER, J., \& LANE, A. Recognition of human faces: Effects of target exposure time, target position, pose position, and type of photograph. Journal of A polied Psychology, 1971,55,477-483.

LAURENCE, $M$. $W$. Age differences in performance and subjective organization in the free-recall learning of pictorial material. Canadian Journal of Psychology, 1966, 20,388-399.

LEASK, J., HABER, R. N., \& HABER, R. B. Eidetic imagery in children: II. Longitudinal and experimental results. Psychonomic Monograph Supplements 1969,3(3, Whole No. 35).

LIEBERMAN, L. R.. \& CULPEPPER, J.T Words versus objects: Comparison of free verbal recall. Psychological Reports. $1965,17,983-988$.

LIU, S.C.. CHAO, C.C., LI, S.-C., KUO C.-Y.. TA1, C.-L., \& MUO, H.-H. A preliminary study on the characteristics of memory for pictorial and verbal materials in primary school children. Acta Psychologica Sinica, 1964, 2, 171-177.

LONDON.P. \& ROBINSON,J. Imagination in learning and retention. Child Development, $1968,39,803-815$.

LORAYNE, M. How to develop super-power memory. New York: Fell, 1957 .

LU BORSKY, L., BLINDER, B., \& MACKWORTH, $N$. Eye fixation and recall of pictures as a function of GSR responsivity. Perceptual \& Motor Skills, $1963,16,469-483$.

LUCAS, D. B. A rigid technique for measuring the impression values of specific magazine advertisements. Journal of A pplied Psychology, 1940, 24 778-790

LUMSDAINE, A. A. Ease of learning with pictorial and verbal symbols. Doctora dissertation, Stanford University, 1949

LURIA. A. R. Memory and the structure of mental processi's.
Psychology, 1960, $4,81-94$

URIA A $\mathrm{R}$.The mind of a mnemonist. New York: Basic Books. 1968

LUSZCZ, M., BARKER, D., \& DA POLITO. F. Effect of stimulus concreteness on recognition accuracy. Perceptual \& Motor Skills, $1972,34,218$.

LYNCH. S.. \& ROHWER, W. Effects of verbal and pictorial elaborations on associative learning and response learning in a children's paired-associate task. Journal of Educational Psychology, 1971. $62,339-344$

LYNCH、S., \& ROHWER, W. Grade interaction with words and pictures in a paired-associate task: A proposed explanation. Journal of Experiment Child Psychology, 1972, 13, 413-421.

M AKHLAKH, E. S. The relationship between visual and verbal types of memory. Voprosy Psikhologii, 1969. 15. 125-127.

MALPASS, R. S., \& KRAVITZ, J Recognition for faces of own and other race. Journal of Personality \& Social Psychology, 1969, 13, 330-334.

M A R X, M ., M URPHY, W. \& BROWNSTEIN, A. Recognition of complex visual stimuli as a function of training with abstracted patterns. Journal of Experimental Psychology, 1961,62. 456-460.

MATHEWS, M., \& FOZARD, J. Age differences in judgments of recency for short sequences of pictures. Developmental Psychology, 1970, 3. 208-217.

MAY, M. A. The psychology of learning from demonstration films. Journal of Educational Psychology, 1946, 37, 1-12.

McFLWEE, E. W. Is a test of visua! memory affected by maturity? Journal of Applied Psychology, 1935, 19, 463-466.

McGEOCH, J, A.. \& WHITELY, P. L. The recall of observed material. Journal of Educational Psychology, 1926, 17, 419-425.

McKEEVER, W., \& HULING, M. Right hemispheric ruperiority in granhir reproduction of briefly viewed dot figures. Perceptual \& Motor Skills, 1970. 31.201 .202

MCKINNEY, F, Retroactive inhibition and recognition memory. Journal of Experimental Psychology, 1935, 18, 585-598.

MEENES, $M$. The incidence of eidetic imagery in negro school children. Journa of Negro Education, 1937, 6, 592-595.

MEENES, M., \& MORTON,M Characteristics of the eidetic phenomenon. Journal of General Psychology, 1936, 14, 370-391.

MELLONE, M. A. A factorial study of picture tests for young children. British Journal of Psychology, 1944, 35, 9-16.

MESSICK, S., \& DAMARIN, F. Cognitive styles and memory for faces. Journal of Abnormal \& Social Psychology, 1964, 69 313-318.

MILGRAM, N. A. Verbal context versus visual compound in paired-associate learning by children. Journal of Experimental Child Psychology, 1967, 5 . $597-603$.

MILGRAM, N., \& RIEDEL. W. Verbal context and visual compound in paired-associate learning of mental retardates. American Journal of Mental Deficiency, 1969, 73, 755-761.

MILLER A \& M CCRIMMON, R. Extinction for systems learning. Psychonomic Science, 1970, 21, 207-208.

MILNER, B. Psychological defects produced by temporal lobe excision. Research Publications of the Association for Nervous \& Mental Disease, 1958, 36. 244-257.

MILNER, B. Visual recognition and recal after rjght temporal lobe excision in man.
Neuropsychologia, 1968,6.191.209.

MOELY, B. E., OLSON, F., HALIVES, T., \& FLAVELL, J. Production deficiency in young children's clustered recall. Developmental Psychology, 1969, 1. 26-34.

MOONEY, C. Recognition of novel visual configurations with and without eye-movements. Journal of Experimental Psychology, 1958, 56, 133-138.

MOONEY, C. Hecognition of symmetrical and non-symmetrical inkblots with and without eye movements. Canadian Journal of Psychology, 1959, 13, 11-19. MOONEY, C. Recognition of ambiguous and unambiguous visual configurations with short and longer exposures. British Journal of Psychology, 1960,51, 119-125

MOORE, T. V. The temporal relations of meaning and imagery. Psychological Review, 1915, 22, 177-225.

MOORE, $T$. I . Image and meaning in memory and perception. Psychological Monographs, 1919, 27 (Whole No, 119). MORAN, L., KIMBLE, J., \& MEFFERD, R. Repetitive psychometric measures: Memory-for-faces. Psychological Reports, 1960. 7, 407-413.

MORELLi, G. Pictures and competing pictures as mediators in paired-associate Jearning. Perceptual \& Motor Skills, 1970. 30.729.730.

MORRIS, P., \& REID, R. The repeated use of mnemonic imagery. Psychonomic Science, $1970,20,337-338$

MORRIS, $P$ \& REID, $R$. Imagery and compatibility of pairing in the free recall of adjective-noun pairs. Quarterly Journal of Experimental Psychology, 1971, 23, 393-398.

MORRIS, P., \& REID, R. Imagery and the recall of adjectives and nouns from meaningful prose. Psychonomic Science, $1972,27.117-118$

MORSH, J. Further investigation of eidetic imagery. Psychological Bulletin, 1942, 39,611 .

MORSH, J., \& ABBOTT, H. An investigaticn of after-images. Journal of Comparative Psychology, 1945, 38. 47-63.

MLELLER, D. J. \& GUMINA, J. Meaning fulness of objects and trigrams as paired-associate stimulus and response. Perceptual \& Motor Skills, 1972. 34, 187-193.

MUELLER 、J., \& JABLONSKI, E. Instructions, noun imagery, and priority in free recall. Psychological Reports. $1970.27,559-566$.

MUELLER, J., \& SLAYMAKER, F. Total time and stimulus-response imagery in pairrd-associate learning. Journal of Experimental Psychology, 1970, 85 . 288-292.

MULHALL, E. F. Experimental studies in recall and recognition. American Journal of Psychology, 1915, 26, 217-228.

MUNSINGER, H. Developing perception and memory for stimulus redundancy. Journal of Experimental Child Psychology, 1967, 5, 39-49.

NELSON, $K$. Memory development in children. Psychonomic Science, 1971, 25, 346-348.

NEWHAIL, $S$ \& HEIM, M. Memory value of absolute size in magazine advertising. Journal of Applied Psychology, 1929, 13, 62-75.

NICKERSON, R Short-term memory for complex meaningful configurations: A demonstration of capacity. Canadian Journal of Psychology, 1965, 19 $155-160$.

NICKERSON, $R$, $S$. A note on long-term recognition memory for picture material. Psychonomic Science, 1968, 11,58.

NODINE, C., \& KORN, J. Role of affect in short-term memory for paired associates. Journal of Experimental Psycholngy. 
$1968,78,494.501$

NORCROSS, K. J., \& SPIKER, C. The effects of type of stimulus pretraining on discrimination performance in preschool children. Child Development, 1957, 28, 79-84.

NOTON, D., \& SPARK, L. Scanpaths in eye movements during pattern perception. Science, $1971,171,308-311$.

NUTT, R. How to develop a good memorv for names, faces, and facts. New York: Simon \& Schuster, 1941

O'CONNOR, N., \& HERMELIN, B. Like and cross modality recognition in subnormal children. Quarterly Journal of Experimental Psychology, 1961, 13, $48-52$

O'CONNOR, N., \& HERMELIN, B. Auditory and visual memory in autistic and normal children. Journal of Mental Deficiency Research, 1967.11,126-131.

OHWAKI, Y. KAIWA, T. \& KAKETA, K. Psychologisch-medizinische Untersuchung der eidetischen Anlage japanischer Jugendlicher. (P s ychomedical investigation on the eidetic disposition among Japanese children.) Tohoku Psychologica Folia, 1934, 2, 57-128.

OJEMANN, G. Alteration in nonverbal short-term memory with stimulation in the region of the mammillothalamic tract in man. Neuropsychologia, 1971. 9, 195-201.

OMBACH, E. Spostrzeganie formalnych cech przedmiotow przez ludzi normalnych i nerwicowcow. (Perception of the formal traits of objects by normal subjects and by neurotics.) Psychologia Wy chow aw cze, $1967,10,75-80$.

O'NEILL, H., \& RAUTH J, Eidetic imagery. Catholic University of America Educational Research Monographs, 1934, $8,22$.

OTTO. W. The differential effects of verbal and pictorial representations of stimuli upon responses evoked. Journal of Verbal Learning \& Verbal Behavior, 1962, 1. 192-196.

OTTO, W., KOENKE, $K$, \& COOPER, $C$. Guoc and poor readeis' learning of verbal and pictorial paired-associate lists. Psychonomic Science, 1968, 11, 347-348.

PAIVIO, A. Abstractness, imagery and meaningfulness in paired-associate learning. Journal of Verbal Learning \& Verbal Behavior, 1965. 4.32-38

PAIVIO, A. Paired-associate learning and free recall of nouns as a function of concreteness, specificity, imagery, and meaningfulness. Psychological Reports, $1967,20,239-245$.

PAIVIO, A. A factor-analytic study of word attributes and verbal learning. Journal of Verbal Learning \& Verbal Behavior. $1968,7,41-49$.

PAIVIO, A. Mental imagery in associative learning and memory. Psychological Review, 1969, 76, 241-263.

PAIVIO, A. On the functional significance of imagery. Psychological Bulletin, 1970. $73,385-392$

PAIVIO, A. Imagery and deep structure in the recall of English nominalizations. Journal of Verbal Learning \& Verbal Behavior, 1971, 10, 1-12.

PAIVIO, A. Imagery and verbal processes. New York: Holt. Reinhart \& Winston, 1971.

PAIVIO, A., \& BEGG, I. Imagery and associative overlap in short-term memory. Journal of Experimental Psychology, $1971.89,40.45$

PAIVIO, A., \& CSAPO, K. Concrete-image and verbal memory codes. Journal of Experimental Psychology, 1969,80 . 279-285.

PAIVIO, A., \& CSAPO, K. Short-term sequential memory for pictures and words. Psychonomic Science, 1971, 24, 50-51.

PAIVIO, A., \& FOTH, D. Imaginal and verbal mediators and noun-concreteness in paired-associate learning: The elusive interaction. Journal of Verbal Learning \& Verbal Behavior, 1970, 9, 384-390.

PAIVIO, A., \& MADIGAN, S. Imagery and association value in paired-associate learning. Journal of Experimental Psychology, 1968, 76, 35-39.

PAIVIO, A \& MADIGAN, S. Noun imagery and frequency in paired-associate and free-recall learning. Canadian Joumal of Psychology, 1970, 24, 353-361

PAIVIO, A., \& OKOVITA, H. Word imagery modalities and associative learning in blind and sighted subjects. Journal of Verbal Learning \& Verbal Behavior, $1971,10,506-510$.

P A I VIO, A. \& OLVER, M. Denotative-generality, imagery, and meaningfulness in paired-associate learning of nouns. Psychonomic Science, $1964,1,183-184$

PAIVIO, A., \& ROWE, E. Noun imagery, frequency, and meaningfulness in verbal discrimination. Journal of Experimental Psychology, 1970, 85, 264-269

PAIVIO, A., \& ROWE, E. Intrapair imagery effects in verbal discrimination and incidental associative leaming. Canadian Journal of Psychology, 1971, 25. 302-312.

PAIVIO, A., \& SMYTHE, P. Word imagery, frequency, and meaningfulness in short-term memory. Psychonomic Science, $1971,22,333-335$

PAIVIO. A.. \& YARMEY, A. Pictures versus words in stimuli and responses in paired-associate learning. Psychonomic Science, $1966,5,235-236$.

PAIVIO, A., \& YUILLE, J. Mediation instructions and word attributes in paired-associate learning. Psychonomic Science. $1967,8,65-66$.

PAIVIO, A., ROGERS, R., \& SMYTHE, P. Why are pictures easier to recall than words? Psychonomic Science, 1968, 11. $137-138$

PAIVIO, A., SMYTHE, P., \& YUILLE, J. Imagery versus meaningfulness of noun in paired-associate learning. Canadian Journal of Psychology, 1968, 22, $427-441$

PAIVIO, A., YUILLE, J., \& MADIGAN, $S$. Concreteness, imagery and meaningfulness values for 925 nouns. Journal of Experimental Psychology Monograph Supplement, 1968, 76 (1, Pt. 2).

PAIVIO, A., YUILLE, J., \& ROGERS, $R$. Noun imagery and meaningfulness in free and serial recall. Journal of Experimental Psychology, 1969, 79, 509-514

PAIVIO, A., YUILLE, J., \& SMYTHE, P. $S t i m u l u s$ and response abstractness. imagery and meaningfulness and reported mediators in paired-associate learning. Canadian Journal of Psychology, 1966, $20,362-377$.

PALERMO, D. S. Imagery in children's learning: Discussion. Psychological Bulletin, 1970, 73, 415-421.

PALLIS, C. A. Impaired identification of faces and places with agnosia for colours. Journal of Neurology, Neurosurgery \& Psychiatry, 1955, 18, 218-224.

PARASKEVOPOULOS, I. Symmetry, recall, and preference in relation to chronological age. Journal of Experimental Child Psychology, 1968,6. $254-264$

PECK, L., \& HODGES, A. A study of the eidetic imagery of young negro children. Journal of Negro Education, 1937, 6 . 601-610

PERKINS, F. Symmetry in visual recall. American Journal of Psvchology, 1932. 44. 473-490.

PERKY. C. W. An experimental study of imagination. American Journal of Psychology, 1910, 21, 422-452.

PERSENSKY, J., \& SENTER, R. An experimental investigation of a mnemonic system in recall. Psychological Record,
$1969,19,491-499$

PERSENSKY. J., \& SENTER, R. An investigation of 'bizarre' imagery as a mnemonic device. Psychological Record, $1970,20,145-150$.

PERSENSKY, J., \& SENTER, R. The effects of subjects' conforming to mnemonic instructions. Journal of Psychology, 1970, 74, 15-21.

PETERSON, $M$. Imagery and the grammatical classification of cues. Journal of Experimental Psychology, $1971,88,307-313$.

PFAFFLIN, $S$. M. Stimulus meaning in stimulus predifferentiation. Journal of Experimental Psychology, 1960, 59 , $269-274$

PHILIP, B. Proactive and retroactive effects in the recognition of form. Journal of Experimental Psychology, 1940,26 , $502-513$.

PIALAT, E Recherches sur la fonction mnémonique de la forme et de la couleur dans les images colorées. (Researches on the mnemonic function of form and colour in coloured images.) Journal de Psychologie, 1929, 26, 101-121.

OST, L. Ancient memory systems. Classical Weekly, 1932, 25, 105-110.

POTTER, M. C., \& LEVY, E. I. Recognition memory for a rapid sequence of pictures. Journal of Experimental Psychology, $1969,81,10-15$.

PRENTICE, W. C. H. Visual recognition of verbally labeled figures. American Journal of Psychology, 1954, 67, 315-320.

PRENTICE, W. C. H., \& ASCH, S. E. Paired association with related and unrelated pairs of nonsense-figures. American Journal of Psychology, 1958, 71, 247-254.

PRICE, R. H. Effects of complexity, association value, and learning on the recognition of random shapes. Canadian Journal of Psychology, 1968, 22, 388-398

PRICE, R., \& HILL, R. Positive transfer of familiarization training to recognition performance: Effects of stimulus complexity and association value. Psychonomic Science, 1968, 11, 283-293.

PRICE, R., \& SLIVE, A. Association value and label relevance in shape recognition. Perceptual \& Motor Skills, 1970, 31. 43-46.

PRICE, R., \& SLIVE, A. Verbal processes in shape recognition. Journal of Experimental Psychology, 1970. 83, 373-379.

PURDY, D. Eidetic imagery and plasticity of perception. Journal of General Fsvehology, 1936, 15, 437-454

PYLES, M. K. Verbalization as a factor in learning. Child Development, 1932, 3. 108-113.

RANKEN, H. B. Effects of name learning on serial learning, position learning, and recognition learning with random shapes. Psychological Reports, 1963, 13 , 663-678.

RANKEN, H. B. Language and thinking: Positive and negative effects of naming. Science, $1963,141,48-50$

RASER, G. A., \& BARTZ, W. Imagery and paired-ass ociate re cognition.
Psychonomic Science, $1968,12,385-386$.

REESE, H. W. Imagery in paired-associate learning in children. Journal of Experimental Child Psychology, 1965, 2, 290-296.

REESE, H. W. Imagery in children's learning: A symposium. Psychological Bulletin, 1970, 73, 383.421

REESE, H. W. Imagery and contextual meaning. Psychological Bulletin, 1970 . $73,404-414$.

REESE, $H$. W. Imagery in children's paired-associate learning. Journal of Experimental Child Psychology, 1970, 9 . 174-178.

REESE, H. W. Imagery and multiple-list paired-associate learning in young 
childrets. Journal of Experimestal ('hild Psrchologv. 1972,13,310-323.

RENDOT, P.. \& TZAVARAS, A. La prosopagnosie après ringt années d'ézudes ciniques et neuropsychologiques. (Prosopagnosia after twenty years of clinical and neuropsychological studies.) Journal de Psychologie Normale tet Pathologique, 1969,66, 133.165.

REY. A. Sollicitation de la mémoire do fixation par des mots et des wbjets presentés simultanement. Archives

Psichologie, $1959-60$

REYNOLDS, J. H. Cognitive transfer in verbal learning. Journal of Educational Psychology, 1966,57,82-388

REYNOLDS. J. H. Cognitive transfer in verbal learning: [1. Transter effects after prefamiliarization with integrated versus partially integrated verbal-perceptual structures. Journal of Educational Psichology, 1968,59,133-138.

REYNOLDS, P. D. Certain effects of the expectation to transmit on concep attainment. Journal of Fducational Psychology, 1968,59,139-146

RICHARDSON, A. Wental imagery. New York: Springer, 1969

RICHARDSON, A.. \& CANT, R. Eidetic imagery and brain damage. Australian Journal of Psychology, 1970, 22, 47-54

RILEY, D A Memory for form In $L$. Postman (Ed.). Psichology in the maling. New York: Knopf, 1962. Chap. 7

RIMIM, D., \& BOTTRELL, J. Four measures of risual imagination. Behavior Research \& Therapy, 1969, 7,63-69.

RIMM, D., ÁLEXANDER, R., \& EILES, R. Effects of different mediational instruc tions and sex of subject on paired-associate learning of concrete nouns. Psychological Reports, 1969, 25, 935-940.

ROBINSON, I. The effect of learning verbal labels for stimuli on their late discrimination. Journal of Experimental Psychology, 1955, 49, 112-114.

ROBINSON, J. Effects of verbal and imaginal learning on recognition. free recall. and aided recal' tests. Journit of Experimental Psychologv. 1970, 86. $115-117$.

ROBINSON, I., \& LONDON, P. Labeling and imagining as aids to memor. Child Development. 1971,42,641-644.

ROCK, I.. \& ENGLESTEIN, P. A study of memory for visual form. American Journal of Psychology, 1959, 72 . $221-229$

R OESSLR. F. Verbreitung und Erscheinungsweise subjektiver optischer Anschauungsbilder bei Knaben und Madchen $1 \mathrm{~m}$ Alter von 6-10 Jahren. (Distribution and appearance of subjective optical eidetic images in bo $\%$ and girls from 6 to 10 years old.) In Untersuchungen uber die eidetische $V$ eranlagung von Kindern und Jugendlichen: Beihefte zum Zejtschrift fir angewandte Psycinologit, 1928. 43 $197-371$

ROHWER, W. D. Verbal and visual elaboration in paired-associate learning. Project Literacs Reports. Comell University, $1966,7,18-28$.

ROHWE. W, D. Images and pictures in children's learning. Psychological Bulletin, 1970,73, 393-403.

ROHWER. W. D.. \& AMMON. M. Elaboration training and paired-associate learning efficiency in children. Journal of Educational Psychology, 1971. 62. $376-383$

ROHWER. W. D., AMMON, M., SUZUKI N.. \& LEVIN, J. Population differences and learning proficiency. Journal of Educational Psychology. 1971, 62, 1-14 ROHWER, W. D., LYNCH, S., LEVIN, J.. \& SUZUKl, N. Pictorial and verbal factors in the efficient learning of paired-associates. Journal of Educational Psychology. 1967.58.278-284

ROHWER, W. D., LYNCH, S.. LEVIN. J.. \&
St:ZUKI. N. Grade level. school strata and learning efficiency. Journal of Educational Psychology, 1968, 59, 26-31

ROHWFR W D.. LYNCH. S., SUZUKI, N \& IEVIN, J. Verbal and pictorial facilitation of paired-associate learning. Journal of Experimental Child Psychology, 1967, 5, 294-302.

ROSENBAUM, M. E. Effect of direct and vicarious verbalization on retention. Child Development. 1962,33,103-110.

ROSENBERG, B. G.. LANGER, H. STEWART, J. Non-verbal learning. American Journal of Psychology, 1969. $82,181-190$

ROSNER, S. The effects of rehearsal and chunking instructions on children's multitrial free recall. Journal o Experimental Child Psychology, 1971. 11.93-105.

ROSS. B. Frequency theory in immediate recognition of nonverbal material. Journal of Experimental Psychology. $1972,92,117-122$

ROSS, B., \& YOCiNiss, J. Ordering of nonverbal items in children's recognition memory. Journal of Experim

ROSS, B., RESNICK, A., \& SPEELMAN, R Recognition memory-span measuremen for nonsense shape orientations and the 'span hold constancy' hypothesis. Psychological Monographs, 1962,76 1-21 (Whole No.545)

ROSS, J., \& LAWRENCE, K. Some bservations on memory artifice. Psvchonomic Science, 1968, 13, 107-108.

ROSSMAN, E. E. Learning from pictures: Performance in a free recall task as a function of age, pretrairing, and structure of materials. Dissertation Abstracts International, 1971, 32, 3624 .

ROSSMAN, I. L., \& GOSS, A. E. The acquired distinctiveness of cues: The role of discriminative verbal responses in facilitating the acquisition of discriminative motor responses. Journal of Psychology, 1951, 42, 173-188.

ROTH, D. H. Roth memory course. Santa Monica, Calif: Motivation, 1961.

ROWE, $\mathrm{E}$, \& PAIVIO, A. Discrimination learning of pictures and words. Psychonomic Science, 1971, 22, 87-88

ROWE, F.. \& PAIVIO,A. Word frequency and imagery effects in verbal discrimination learning. Journal of Experimental Psychology, 1971, 88, 319-326.

RUNQUIST, $W$ N \& HUTT $V$ Verbal concept learning in high school students with pictorial and verbal representation of stimuli. Journal of Educational Psychology, 1961,52,108.111.

RYAN, S., HEGION A. \& FLAVELL, J Nonverbal mnemonic mediation in preschool children. Child Development. $1970,41,539-550$.

RYTAL, M. La mémorisation et les schèmes conceptuelles. (Memorization and conceptual schemes.) Travaux de Laboratoire de Psychologie Experimentalle d'Université de Cracovie. $1938,2,158-218$

SAMPSON, J. Intluence of rehearsal on serial-position effects in immediate free recall. Psychological Reports. 1969, 25. 893-894.

SA.MPSON, J. Further study of encoding and arousal factors in free recall of verbal and visual material. Psychonomic Science $1969,16,221-222$

SAMPSCN, J. Free recall of verbal and non-verbal stimuli. Quarterly Journal of Experimental Psychology, 1970. 22 $215-221$

SAMUEIS, I., BUTTERS. N., \& GOOISLASS, H. Visual memory deficits following cortical and limbic lesions: Effect of field of presentation. Physiology \& Behavior, $1971,6.447-452$. SAMUFLS, S. Attentional process in reading. The effect of pictures on the acquisition of reading responses. Journal of Edurational Psychology, 1967, 58 , 337-342.

SAIUUES $\mathbf{S}, 1$ Effects of pictures on fearning to read, comprehension, and attitudes. Review of Fducationa: Research, 1970, 40, 397-407.

SANG, D.. \& ROSS, J. The verbal-loop hypothesis (VLH): A within-subject siudy with a perceptual recognition task. Psychonomic Science, 1970, 18, 345-347.

SANTA, J., \& RANKEN, H. Language and memory: Redintegrative memory for shapes facilitated by naming. Psychonomic Science, 1968, 13, 109

SANTA, J. L.. \& RANKEN, H. Effects of verbal coding on recognition memorv. Journal of Experimental Psychology. $1972,93,268-278$

SASSON. R. Interfering images at sentence retrieval. Journal of Experimental Psychology, 1971,89,56-62.

SASSON, R. Y.. \& FRAISSE, P. Images in memory for concrete and abstract sentences. Journal of Experimentid Psychology, 1972, 94, 149-155.

SCAPINELLO, $K$ \& YARMEY, A. The role of familiarity and orientation in immediate and delayed recognition of pictorial stimuli. Psychonomic Science, 1970. $21.329-331$.

SCH il T F Experimentelle Untersuchungen über die Wirkung ahnlicher Inserate und Figuren. (Fxperimental studies on the effects of similar advertisements and figures.) Archiv für die gesamte Psychologie. 1927. 60. $417-456$.

SCHNORE, M. M.. \& PARTINGTON,J. Immediate memory for visual patterns: Symmetry and amount of information. Psychonomic Science, 1967, 8, 421-422. SCHNORR, J.. \& ATKINSON, R. Repetition versus imagery instructions in the short- and long-term retention of paired-associates. Psychonomic Science. $1969,15,183-184$

SCHNORR, J., \& ATKINSON, R. Study position and item differences in the shortand long-term retention of paired-associates learned by imagery. Journal of Verbal Learning \& Verbal Behavior, $1970,9,614-622$

SCOTT $K$ Clustering with perceptual and symbolic stimuli in tree recall. Journal of Verbal Learning \& Verbal Behavior. $1967,6,864-866$

SEFLEMAN. $V$. The influence of attitude Loon the remembering of pictorial ruaterial. Archives of Psychologv, New York, $1940,258,69$.

SEGAL, S. J. (Ed.) Imagery current cognitile approaches. New York: a cademic Press. 1971.

SEGAL. S. J.. \& FUSELLA, V. Effects of imaging and modes of stimulus onset on signal-to-noise ratio. British Journal of I'suchology, 1969,60, 459-464.

SEGAI S J \& FUSELI \& $V$. Influence of imaged pictures and sounds on detectior (f) visuad and auditory signals. Journal of Experimental Psychology, 1970, 8. 458.464.

SEGAL, S. J., \& FUSELLA, V. Effect ot images in six sense modalities on detection of risual signal from noise. Fsychonomic Science, $1971,24,55-56$.

SEGAL, S. J.. \& GLICKSMAN, 11 Relaxation and the Perky effect: The influenct of body position on judgements () $f$ imagery. American Jour

PSychology, $1967,80,257-262$.
SEGAL. S. J. \& GORDON,P.E. The Perks iffect revisited: Blocking of visual signals by imagerv. Perceptual \& Motor Skills. $1969,28,791.797$

SEIDENFFI.D. M. Time as a factor in the recognition of visually perceived figures. American Journal of Psychology, 1938. $51.64-82$

SEMILER. I. J.. \& ISCOE. I. Comparative and developmental study of the learning 
abilities of Negro and White children under four conditions. Journal of Educational Psychology, 1963, 54, 38-44. SEMLER, I. J., \& ISCOE, I. Concept interference and paired associates in retarded children. Journal of Comparative \& Physiological Psychology, 1965, 60. 465-466.

SENTER, R., \& HAUSER, G. An experimental study of a mnemonic system. Psychonomic Science, 1970, 10. 289-290.

SHAFFER, W., \& SHIFFRIN, R. Rehearsal and storage of visual information. Journal of Experimental Psychology, 1972, 92 292-296.

SHARP, A. The diagnostic significance of a visual memory drawing test. Journal of Abnormal \& Social Psychology, 1949, 44 $517-527$.

SHEEHAN, P. Accuracy and vividness of visual images. Perceptual \& Motor Skills, $1966,23,391-398$

SHEEHAN, $P$. Visual imagery and the organization properties of nerceived stimuli. British Journal of Psychology, $1967,58,247-252$

SHEEHAN, $P$. Individual differences in vividness of imagery and the function of imagery in incidental learning. Australian Journal of Psychology, 1971, 23, 279-288

SHEEHAN, P. W. The role of imagery in incidental learning. British Journal of Psychology, 1971, 62, 235-243.

SHEEHAN, P. \& NEISSER U. Som variables * affecting the vividness of imagery in recall. British Journal of Psychology, 1969, 60,71-80.

SHEPARD, $R$. Recognition memory for words, sentences, and pictures. Journal of Verbal Learning \& Verbal Behavior $1967,6,156-163$.

SHEPARD, R. N.. \& CHIPMAN, S Second-order isomorphism of internal representations: Shapes of states. Cognitive Psychology, 1970, 1, 1-17

SHEPARD, R. N., \& METZLER, J. Mental rotation of three-dimensional objects. Scit nce, 1971, 171, 701-703.

SIIPOLA, E., \& HAYDEN. S. Exploring eidetic imagery among the retarded. Perceptual \& Motor Skils, 1965, 21 $275-286$

SMIRNOV, A. A. Voprosy psikhologii pamiati. (Problems in the psychology of memory.) Moscow, USSR: RSFSR Academy Pedagogical Sciences, 1958 . $216 \mathrm{p}$

S M I T H , E., \& N I E L S E N , G Representations and retrieval processes in short-term memory: Recognition and recall of faces. Journal of Experimental Psychology, 1970, 85, 397-405.

SMITH, E., \& SLOBODA, W. Some relations between affect and recall: An exploratory study. Psychonomic Science. $1968,12,257-258$

SMITH, $M$. The reproduction of colour patterns. British Journal of Psychology, $1934,25,63-76$

SMITH, R. K., \& NOBLE, C. Effects of mnemonic technique applied to verbal learning and memory. Perceptual \& Motor Skills, 1965, 21, 123-124.

SMYTHE, P. C. Paix concreteness and mediation instructions in forward and backward paired-associate recall. Doctoral dissertation, University of Western Ontario, 1970

SMYTHE, P.\& PAIVIO A A comparison of the effectiveness of word imagery and meaningfulness in paired-associate learning of nouns. Psychonomic Science, $1968,10,49-50$.

SORGE, S. Neue Versuche über die Wiedergabe abstrakes optischer Gebilde. (A new experiment on the reproduction of abstract optical forms.) Archiv für die gesamte Psychologie, 1940, 106, 1-89.

SPANGENBERG, R. W. Structural coherence in pictorial and verbal displays. Journal of Educational Psychology, 1971 .
$62,514-520$.

SIKER, C. S., \& NORCROSS, K. Effects of previously acquired names on discrimination performance. Child Development, 1962, 33, 859-864.

SPOERL, D. Effect of pictures upon recall of stories told orally. Child Development $1937,8,295-298$

STANDING, L. Learning 10,000 pictures Quarterly Journal of Experimental sychology, in press.

STANDING, L. CONEZIO, J \& HABER R. Perception and memory for pictures Single trial learning of 2,500 visua stimuli. Psychonomic Science, 1970, 19 73-74.

STANDING, L., SELL, C., BOSS, J., \& HABER, R. N. Effect of visualization and subvocalization on perceptual clarity Psychonomic Science, 1970, 18, 89-90.

STEVENSON, H., \& SIEGEL, A. Effects of instructions and age on retention of filmed content. Journal of Educational Psychology, 1969, 60, 71-74

STEWART, J. An experimental nvestigation of imagery. Dissertation Abstracts, 1966, 27, 1285 .

STRATTON, G. The mnemonic feat of the Shass Pollak,' Psychological Review, $1917,24,44-46$

STROMEYER, C. \& PSOTKA, J The detailed texture of eidetic images. Nature, $1970,225,346-349$

STRONG, E. The effect of length of series pon recognition memory Psychological Review, $1912,19,447-462$

SYMMES, J. Visual imagery in brain-injured children. Proceedings of the Annual Convention of the American Psychological Association, 1971, 6 $179 \cdot 180$.

TEASDALE, H. A quantitative study of eidetic imagery. British Journal of Educational Psychology, 1934,4,56-74.

THORNDIKE, E. L. On the function of visual images. Journal of Philosophy, $1907,4,324-327$.

TIERNAN, J The principle of closure in terms of recall and recognition. American Journal of Psychology, 1938,51,97-108

IRAXEL. W. Kritische Untersuchungen zur Ejdetik. (Critical examination of eidetic imagery,) Archiv für die gesamte Psychologie, 1962, 114, 260-336.

TRESSELT, M. The influence of suggestion on the recognition of visually perceived forms. Journal of General Psychology, $1948,39,259-271$.

TSAO, J. C. A study in the recognition of figures. British Journal of Psychology, $1949,40,57-67$

TULVING, E., McNULTY, J \& OZIER, M Vividness of words and learning in free-recall learning. Canadian Journal of Psychology, 1965,19, 242-252.

TVERSKY. B. Pictorial and verbal encoding in a short-term memory task. Perception \& Psychophysics, 1969,6, 225-233.

TZAVARAS, A., HECAEN, H., \& LE BRAS, H. Le problème de la spécificité du déficit de la reconnaissance du visage humain lors des lésions hémispheriques unilatérales. (The problem of specificity of inadequate recognition of the human face after hemispheric unilateral lesions, Neuropsychologia, $1970,8,403-416$.

URBANO, R., SCOTT, K., \& M CCARTHY, K. Recognition memory: The relationship of accuracy and latency of response under different memory loads in retardates. Journal of Experimental Child Psychology, 1971, 12, 270-277.

VANCE, B. J., \& SIEGEL, A The relative effectiveness of observing response vs predifferentiation pretraining on children's discrimination learning. Psychonomic Science, 1971, 24, 183-185.

VANDER MEER, A. W. Color versus black and white in instructional films. AV Communication Review, 1954, 2, 121-134.

VANDERPLAS, I. M. Transfer of training and its relation to perceptual learning and recognition. Psychological Review, 1958 , $65,375 \cdot 385$

VANDERPLAS, J. M., \& GARVIN, E. The association value of random shapes. Journal of Experimental Psychology, $1959,57,147-154$

VANDERPLAS, J., \& GARVIN, E. Complexity, association value, and practice as factors in shape recognition following paired-associates training. Journal of Experimental Psychology. $1959,57,155-163$

VERNON, M. D. Learning from graphical material. British Journal of Psychology, $1946,36,145-158$

VERNON, $M$. D. The use and value of graphical material with a written text. Occupational Psychology, 1952, 26, 96-100.

VERNON, $M$. D. The value of pictorial illustration. British Journal of Educational Psychology, 1953, 23, 180-187.

VERNON, M. D. Perception and understanding of instructional television programmes. British Journal of psychology, 1953,44, 116-126.

VER NON, M. D. The instruction of children by pictorial illustration. British Journal of Educational Psychology, 1954, 24. 171-179.

VOGELSANG, H. Experimentelle Untersuchungen über die Einprägung simultan gebotener Objekte. (Experimental investigations concerning the memorizing of objects presented simultaneously.) Archiv für die gesamte Psychologie, 1929, 67, 257-306.

VOICU, C. Influence of the level of bioelectrical arousal on the mnemic efficiency of verbal and non-verbal stimuli. Revue Roumaine des Sciences Sociales-Série de Psychologie, 1970, 14. 151-162.

WACHTEL, J. Obrazy ejdetcyzne nastepcze $w$ przestrzeni zwierciadlanej. Donicsienie tymczasowe. (Eidetic images and after-images in mirrored space. A preliminary note.) Kwartalnik psychologiczny, 1932, 3, 439.446.

WACHTEL, J. Studjum eidetyzmu wsrod doroslych. (Expeximents on eidetic disposition in adults.) Kwartalnik psychologiczny, 1934, 5, 394-401.

WALKER, E. \& VEROFF, J. Changes in the memory-trace for perceived forms with successive reproductions. American Journal of Psychology, 1956, 69, 395-402.

VALKER, H. Interaction of imagery, associative overlap, and category membership in multitrial free recall. Journal of Experimental Psychology, $1971,88,333-339$

WALLACE, G., COLTHEART, M., \& FORSTER, K. Reminiscence in recognition memory for faces. Psychonomic Science, 1970, 18, 335-336.

WALLACH, H., \& AVERBACH, F. On memory modalities. American Journal of Psychology, 1955, 68, 249-257.

WALLON, H., \& EVART-CHMIELNISKI, E. Les mécanismes de la mémoire en rapport avec ses objets. (The mechanisms of memory as related to its objects.) Paris: Presses Universitaires de France. 1951.

WARD, L. C., \& SIEGEL, P. Effects of delay of reinforcement and stimulus meaningfulness on the discrimination learning of retardates at two intelligence levels. Psychonomic Science, 1971.23. $395-396$

WARRINGTON, $\mathrm{E}$, \& JAMES. M. Disorders of visual perception in patients with localized cerebral lesions. Neuropsychologia, 1967, 5, 253-266.

WARRINGTON, E., \& JAMES, M. An experimental investigation of facial recognition in patients with unilateral cerebral lesions. Cortex, 1967, 3. 317-326. 
WARRINGTON, E., \& RABIN, P. A preliminarv investigation of the relation between risual perception and visual memory. Cortex, 1970, 6, 87-96.

WARRINGTON, E.. \& RABIN, P. Visual span of apprehension in patients with unilateral cerebral lesions. Quarterly Journal of Experimental Psychology, $1971,23,423-431$.

WARRINGTON, E.. \& SANDERS, $H$. The fate of old memories. Quarterly Journal of Experimental Psychology, 1971, 23. 432-442.

WEARING, A. J. Vividness in the recall of English nominalizations. Psychonomic Science, 1971,22,121-122.

WEIGL, E. MI I A ILESCU, L.. SEWASTOPOL, N.. \& LANDER, J. Zur Psychologie und Pathologie des Bilderkennens. (Psychology and pathology of picture recognition.) Zeitschrift für Psychologie, 1967. 173. 45-76.

WEINLAND, J. D. Hou to improve your memory. New York: Barnes \& Noble. 1957

WEIR, M. W. \& STEVENSON, H. The effect of verbalization in children's learning as a function of chronological age. Child Development, 1959, 30 , 143-149.

WELLS, J. E. Encoding and memory for verbal and pictorial stimuli. Quarterly Journal of Experimental Psvchology $1972,24,242-252$.

WHITELY, P. \& McGEOGH, J. The effect of one form of report upon another. American Journal of Psychology, 1927 $38,280-284$.

WHITMAN, J. \& ANDERSON, E. Transfer effects in part to whole free-recall learning. Psychonomic Science, 1970, 21 , 109-111.

WHITMAN, J., \& GARNER, W. Free recal learning of visual figures as a function of form of internal structure. Journal of Experimental Psychology, 1962. 64, 558-564.

WICKENS, D. \& ENGLE. R. Imagery and abstractness in short-term memory. Journal of Experimental Psychology. $1970,84,268-272$

WICKFR. F. On the locus of picture-word differences in paired-associate learning. Journal of Verbal Learning \& Verbal Behavior, 1970, 9, 52-57.

WICKER, F. Photographs, drawings, and nouns as stimuli in paired-associate learning. Psychonomic Science, 1970, 18. 205-206.

WICKER. F. Continuous restricted associations to pictorial and verbal items. AV Communication Review, 1970, 18 $431-439$.

WICKER, F. Pictures, words, and imagery mediation in paired-associate learning. Perceptual \& Motor Skills, 1971,33, 135-144.

WICKER, F. \& EVERTSON, C. M Prerecall and postrecall imagery ratings with pictorial and verbal stimuli in paired-associate learning. Journal of Experimental Psychology, 1972, 92 .
$75-82$.

WICKER, F., \& HOLLEY, F. Distraction modality and stimulus modality in paired-associate learning. Psychonomic Science, $1971,25,218-220$.

WILGOSH, L. Interaction between pictures and their labels in the memory of four-year-old children. Doctoral dissertation, McMaster University, 1970.

WIMER, C., \& LAMBERT, W. The differential effects of word and object stimuli on the learning of paired associates. Journal of Experimental Psychology, 1959, 57, 31-36.

WITECKI, K. The role of children's interest in the memory process. Roczniki Filozoficzne, 1963,9,93-101.

WOLLEN, K. A., \& LOWRY, D. H. Effecis of imagery on paired-associate learnung. Journal of Verbal Learning \& Verbal Behavior, 1971, 10, 276-284.

WOLLEN, K. A., FOX, R. A.. \& LOWRY. D. H. Variations in asymmetry as a function of degree of forward learning. Journal of Experimental Psychology. $1970,86,416 \cdot 419$

WOLLEN, K. A. WEBER, A.. \& LOWRY D. Bizarreness versus interaction of mental images as determinants of learning. Cognitive Psychology, 1972, 3 , 518-523.

WOOD $G$ Mnemonic systems in recall. Journal of Educational Psychology Monographs, $1967,58,1-27$

WOOD, G., \& BOLT, M. Type of instruction, abstractness and mnemonic system. Psychonomic Science, 1970, 21 , 91-92.

WRIGHT, J. C.. \& SMOTHERGILL, D Observing behavior and children's discrimination learning under delayed reinforcement. Journal of Experimental Child Psychology, 1967, 5, 430-440.

YAKIM ANSKAYA, I. Obraznoe myshlenie ego mesto $v$ obuchenii. (Visual imagery and its place in learning.) Sovetskaya Pedagogika, 1968, 32,62-71.

YARMEY, A. Concreteness, imagery and temporal factors in paired-associate learning. Psychonomic Science, 1967, 8 417-418.

YARMEY, A. The effect of mnemonic instructions on paired-associate recognition memory for faces or names. Canadian Journal of Behavioral Science, 1970,2 . 181-190.

YARMEY, A. Recognition memory for familiar 'public' faces: Effects of orientation and delay. Psychonomic Science, $1971,24,286-288$

YARMEY, A.. \& BARKER, W. Repetition versus imagery instructions in the immediate and delayed retention of picture and word paired-associates. Canadian Journal of Psychology. 1971 . $25,56-61$.

YARMEY, A., \& CSAPO, K. Imaginal and verbal mediation instructions and stimulus attributes in paired-associate learning. Psychological Record, 1968. 18. 191-199.

YARMEY, A., \& O'NEILL, B. S-R and R-S paired-associate learning as a function of concreteness, imagery, specificity, and ssociation value. Journal of Psychology. $1969,71,95-109$

YAFMEY A. \& THOMAS, $K$, Set and word abstractness-concreteness shift in paired-associate learning. Psychonomic Science, 1966,5, 387-388.

YARMEY, A., \& URE. G. Incidental learning, noun imagery-concreteness and direction of associations in paired-associate learning. Canadian Journal of Psychology, 1971, 25, 91-102.

YARMFY A O'NFILL B \& DE RYK D. Stimuius and response concreteness, imagery, and temporal factors in paired-associate learning. Psychonomic Science, 1968, 13, 321

YATES. F. The art of memory. London: Routledge \& Kegan Paul, 1966.

YIN, R. Looking at upside-down faces. Journal of Experimental Psychology, $1969.81,141-145$

YIN, R. Face recognition by brain-injured patients: A dissociable ability? Neuropsychologia. $1970,8,395-402$.

Y OSHIMURA, E., MOELY, B., \& SHAPIRO. S. The influence of age and vresentation order upon children's free recall and learning to learn. Psychonomic Science, $1971,23,261-263$

YUILLE, J. Concreteness without imagery in PA learning. Psychonomic Science. $1968,11,55.56$

YLILI.E, J. C. Does the concreteness effect reverse with delay? Joumal of Experimental Psychology, 1971, 88. 147-148.

YUILLE, J., \& PAIVIO, A. Latency of imaginal and verbal mediators as a function of stimulus and response concreteness-imagery. Journal of Experimental Psychology, 1967, 75. 540-544.

YUILLE, J., \& PAIVIO, A. Imagery and verbal mediation instructions in paired-associate learning. Journal of Experimental Psychology, 1968, 78, 436-441

YUILLE, J., \& PRITCHARD, S. Noun concreteness and verbal facilitation as factors in imaginal mediation and $P A$ learning in children. Journal of Experimental Child Psychology, 1969, 7, $459-466$

YUILLE, J PAIVIO, A \& LAMBERT, W Noun and adjective imagery and order in paired-associate learning by French and English subjects. Canadian Journal of Psychology. 1969, 23, 459-466.

ZANGWILL, $O$ An investigation of the relationship between the processes of reproducing and recognizing simple figures, with special reference to Koffka's trace theory. British Journal of Psychology, 1937, 27, 250-276.

ZANGWILL, $O$. A study of the significance of attitude in recognition. British Journal of Psychologv, 1937, 28, 12-17.

ZIMMERMAN, R., \& HOCHBERG, J. Responses of infant monkeys to pictorial representations of a learned visual discrimination. Psychonomic Science. 1970, $18,307-308$. 